Review

\title{
Development of Protein- and Peptide-Based HIV Entry Inhibitors Targeting gp120 or gp41
}

\author{
Jing Pu ${ }^{1,+}$, Qian Wang ${ }^{1,+}$, Wei $\mathrm{Xu}^{1}{ }^{1}$ Lu Lu ${ }^{1, * \mathbb{C}}$ and Shibo Jiang ${ }^{1,2, *}$ \\ 1 Shanghai Public Health Clinical Center and School of Basic Medical Sciences, Key Laboratory of Medical \\ Molecular Virology (MOE/NHC/CAMS), Fudan University, Shanghai 200032, China \\ 2 Lindsley, F. Kimball Research Institute, New York Blood Center, New York, NY 10065, USA \\ * Correspondence: lul@fudan.edu.cn (L.L.); shibojiang@fudan.edu.cn (S.J.); \\ Tel.: +86-21-5423-7671 (L.L.); +86-21-5423-7673 (S.J.) \\ + These authors contributed equally to this work.
}

Received: 9 July 2019; Accepted: 30 July 2019; Published: 1 August 2019

check for updates

\begin{abstract}
Application of highly active antiretroviral drugs (ARDs) effectively reduces morbidity and mortality in HIV-infected individuals. However, the emergence of multiple drug-resistant strains has led to the increased failure of ARDs, thus calling for the development of anti-HIV drugs with targets or mechanisms of action different from those of the current ARDs. The first peptide-based HIV entry inhibitor, enfuvirtide, was approved by the U.S. FDA in 2003 for treatment of HIV/AIDS patients who have failed to respond to the current ARDs, which has stimulated the development of several series of protein- and peptide-based HIV entry inhibitors in preclinical and clinical studies. In this review, we highlighted the properties and mechanisms of action for those promising protein- and peptide-based HIV entry inhibitors targeting the HIV-1 gp120 or gp41 and discussed their advantages and disadvantages, compared with the current ARDs.
\end{abstract}

Keywords: HIV-1; gp120; gp41; entry inhibitor; peptide; antibody; recombinant protein; antiretroviral drugs

\section{Introduction}

According to UNAIDS, approximately 36.9 million people worldwide were living with human immunodeficiency virus (HIV) in 2017 (https://www.unaids.org). The introduction of highly active antiretroviral drugs (ARDs) mainly includes nucleoside/nonnucleoside reverse transcriptase inhibitors (NRTIs/NNRTIs), protease inhibitors (PIs), and integrase inhibitors (INIs). However, the long-term use of ARDs has caused the emergence of multi-drug resistant HIV strains, resulting in more and more treatment failure [1,2]. In 2003, the first peptide-based HIV entry inhibitor, enfuvirtide, was approved by the U.S. FDA for clinical use to treat HIV/AIDS patients who failed to respond to the current ARDs. Most ARDs must enter the host cells to target the enzymes required for HIV replication. Instead, HIV entry inhibitors do not enter the host cell, but rather, act outside the cells and block HIV entry into the target cells by interacting with the envelope glycoproteins (Env) on the surface of the virion. So far, a series of protein- and peptide-based HIV entry inhibitors have been developed in preclinical and clinical studies.

HIV-1 Env (approximately 160 kD, also known as gp160) is comprised of two noncovalently bound subunits (surface subunit gp120 and transmembrane subunit gp41) upon maturity and plays key roles in viral entry. Such entry is initiated by binding of gp120 to the CD4 receptor (Figure 1a), inducing viral recognition, proximity to the cell, exposure of the coreceptor binding sites (CoRbs), CCR5 or CXCR4 (Figure 1b). A conformational change of the gp120-gp41 complex results in the release of gp41 subunit and triggers fusion of the viral-cell membrane. Specifically, fusion peptide (FP) inserts 
into the target cell membrane and forms an extended prehairpin intermediate (PHI) conformation and links the virus to the cell membrane (Figure 1c). PHI undergoes a further conformational change in which three N-terminal heptad repeats (NHRs) form the inner core and then three C-terminal heptad repeats (CHRs) encapsulate the NHR trimer in an anti-parallel manner to form a six-helix bundle $(6 \mathrm{HB})$ (Figure 1d), thereby forming a fusion pore and causing release of the HIV-1 genome for target cell entry (Figure 1e).

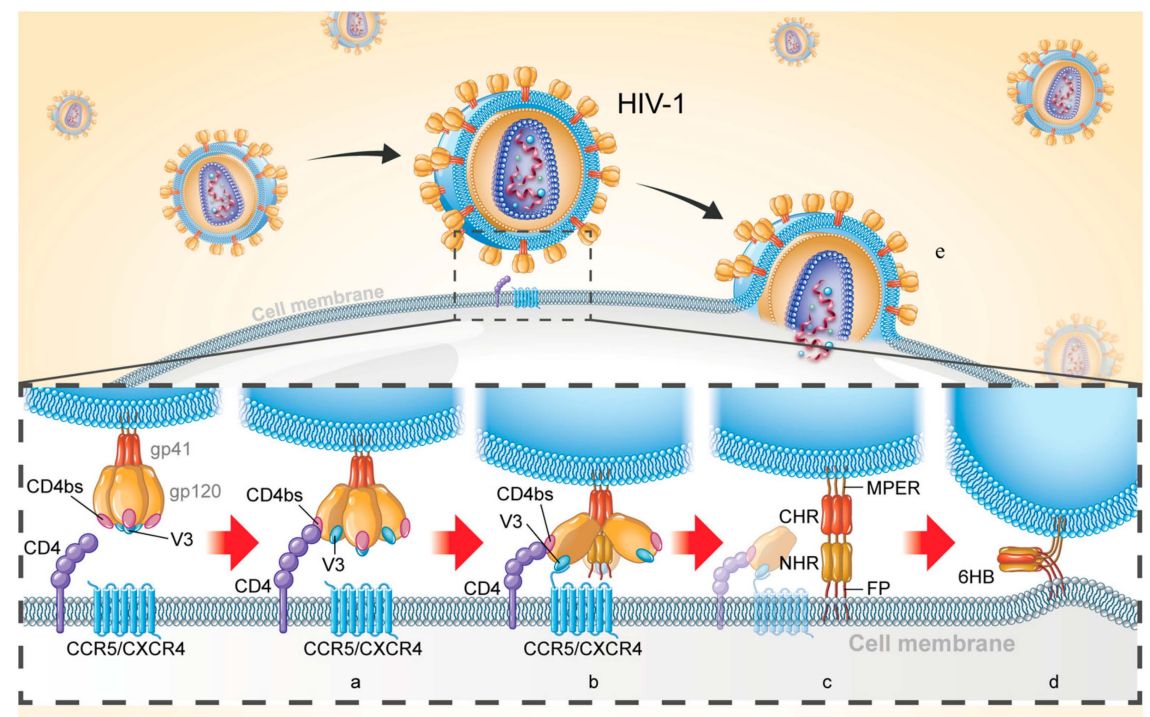

Figure 1. Schematic diagram of HIV-1 entry into target cell. (a) Binding of gp120 to CD4 receptor; (b) Binding of gp120 to the coreceptor CCR5 / CXCR4; (c) Formation of prehairpin intermediate (PFI) and connection of viral membrane and cell membrane; (d) Formation of six-helix bundle (6HB); (e) HIV-1 releases its genome into target cells.

A variety of substances work cooperatively and synergistically during viral-cell membrane fusion and create complex interactive networks involving a variety of protein-protein interactions, such as CD4-gp120 [3-5], gp120-CCR5 / CXCR4 [6], gp120-gp41 [7,8], gp41 NHR-CHR [9], and interaction between the intracellular and extracellular regions of gp41 [10]. Entry inhibitors target these proteins, their interfaces, or other sites to block viral invasion and can be divided into three major subclasses: adhesion inhibitors, targeting CD4 or gp120 to block CD4-gp120 interaction; coreceptor inhibitors, targeting CCR5 or CXCR4 to inhibit the binding of gp120 to the coreceptor; and fusion inhibitors, targeting gp41 to interfere with its conformational change required for viral fusion and entry. In addition, inhibitors targeting both gp120 and gp41, which may have stronger inhibitory activity and higher genetic barrier, are also at the forefront of current research. In this review, we will discuss the characteristics of protein- and peptide-based inhibitors that specifically target HIV Env and look ahead to their development.

\section{Protein-and Peptide-Based HIV Entry Inhibitors Targeting gp120}

The HIV-1 Env surface subunit gp120 contains 5 conserved constant regions (C1-C5) and 5 variable regions (V1-V5) and plays an important role in initiating and controlling HIV-1 infection [6,11,12] (Figure 2A). The N332 glycoprotein, CD4-binding site (CD4bs), and V1-2 loops are conserved sites targeted by many antibodies (Figure 2B). Recently, the structure of the gp120 V3 loop interacting with the chemokine binding pocket in CCR5 and the interaction of the CD4-induced bridging sheet of gp120 with the N-terminus of CCR5 have been resolved, revealing key coreceptor binding residues in gp120 [6], providing detailed structural information for gp120-coreceptor interaction. This key structural information provides the basis for analyzing the interaction between inhibitors and viruses, as well as helping to further the design of optimized inhibitors. 


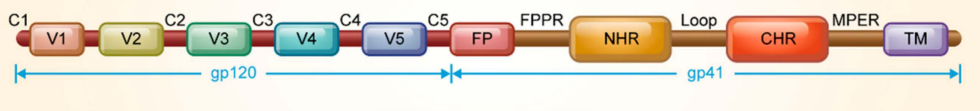

в

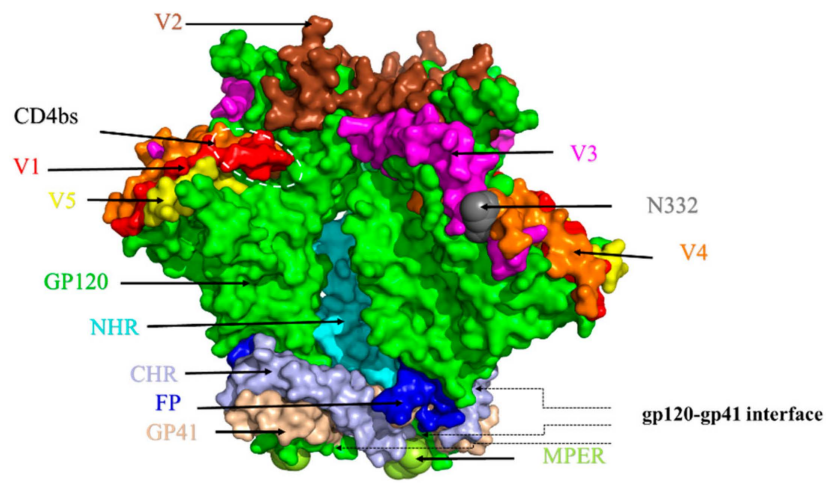

Figure 2. Ectodomain structure of HIV-1 Env trimer. (A) Schematic diagram of HIV-1 gp120 and gp41. (B) Side view of the Env trimer. Gp120 is colored in green with the V1, V2, V3, V4, and V5 regions colored in red, brown, purple, orange and yellow, respectively. CD4bs is marked with a white dotted frame. Gp41 is colored in light pink with the fusion peptide (FP), N-terminal heptad repeats (NHR), C-terminal heptad repeats (CHR) and membrane-proximal external region (MPER) regions colored in blue, cycan, bright gray and cycan-blue, respectively. The images were generated with the software PyMOL according to the PDB ID: 5VJ6.

\subsection{Antibodies or Recombinant Proteins Targeting gp120}

\subsubsection{Antibodies or Recombinant Proteins Targeting gp120 CD4bs}

The gp120 CD4bs-Targeting Antibodies

VRC01, VRC02, and VRC03 are broad-spectrum neutralizing antibodies isolated from B cells of HIV-1-infected individuals, partially mimicking the interaction of CD4 receptor with gp120 [13]. Studies have shown that VRC01 interacts primarily with three regions of gp120, including loop D, CD4bs, and V5, causing a conformational change in gp120 such that its binding to CD4 receptor is blocked. In terms of neutralizing activity, VRC01 is similar to that of VRC02 and greater than that of VRC03 [14]. Unfortunately, the cell-cell fusion inhibitory activity of VRC01 is significantly reduced [15], and VRC01-resistant strains appeared [16-18]. NIH45-46 are more potent VRC01 mutants screened from the HIV-1 antibody library using single-cell cloning technology [19]. Both are from the same patient and currently undergoing clinical trials. NIH45-46 ${ }^{\mathrm{G} 54 \mathrm{~W}}$ is a structure-based NIH45-46 mutant that enhances interaction with the gp120 bridging sheet. Compared with NIH45-46 and VRC01, NIH45-46 ${ }^{\mathrm{G} 54 \mathrm{~W}}$ has a wider neutralization profile and a 10-fold or 20-fold increase in neutralizing activity [20]. 45-46 $\mathrm{m} 2$ and $45-46 \mathrm{~m} 7$ are NIH45-46 ${ }^{\mathrm{G} 54 \mathrm{~W}}$ mutants based on the NIH45-46-gp120 complex structure and the NIH45-46 ${ }^{\mathrm{G}} 4 \mathrm{~W}$ resistant strain sequence analysis design. The activity of $45-46 \mathrm{~m} 2$ was similar to that of NIH45-46 ${ }^{\mathrm{G} 54 \mathrm{~W}}$, and it was greater than that of 45-46 m7. However, the 45-46 m2-neutralizing NIH45-46 resistant strain was more effective than NIH45-46 ${ }^{\mathrm{G} 54 \mathrm{~W}}$ [21]. Combination therapy of 45-46 $\mathrm{m} 2$ and $45-46 \mathrm{~m} 7$ in mice infected with HIV-1 reduced viral escape. N6 is a bNAb isolated from an HIV-infected patient, and it targets the gp120 CD4bs. It has more effective neutralizing activity than VRC01, and inhibits the VRC01-resistant strain. This could be attributed to the dependence of N6 on the conserved region of gp120 and avoidance of the interaction of its light chain with the gp120 V5 region, which is considered to be a major factor in the resistance of the virus to VRC01-class antibodies [22]. In a non-human primate model, mutants of N6 show significant antiviral effects [23]. Currently, N6 is undergoing clinical trials to assess whether it can safely inhibit HIV-1 infection in 
humans. 3BNC117 is an HIV-1 patient-derived bNAb that targets the gp120 CD4bs [19]. The results of non-human primates showed that 3BNC117 or 3BNC117 combined with PGT121 significantly reduced the viral load of SHIV [24,25] and that it had long-term protective effects against repeated low-dose SHIV challenges [26]. The first phase of clinical trials showed that 3BNC117 has good pharmacokinetic properties and is effective in inhibiting viremia in HIV-1-infected patients for up to 28 days, although some patients developed 3BNC117-resistant strains in a short period of time [27]. It is worth noting that passive immunization of 3BNC117 accelerates the clearance of infected cells [28]. Phase IIa clinical trial data show that 3BNC117 can effectively inhibit viral rebound in patients with treatment interruption [29]. In addition, cellular immunity and humoral immunity to HIV-1 were found in patients treated with 3BNC117 [30,31]. PGV04 (also known as VRC-PG04) is a gp120 CD4bs-targeting bNAb isolated from an elite controller infected with an HIV-1 clade A1/D recombinant [32]. It exhibits broad-spectrum and neutralizing activity similar to that of VRC01 and 3BNC117, but the latter two were isolated from patients infected with a single subtype of HIV-1; therefore, the induction of bNAb targeting CD4bs is not dependent on viral subtype because these CD4bs-specific bNAbs have different CD4bs recognition patterns and different ways to access the CD4bs [33].

F105, an IgG1 kappa antibody targeting a discontinuous epitope on gp120, was identified in the early 1990s. Subsequently, the neutralization activity was evaluated [34]. The co-crystal structure shows that its conformation for gp120 recognition is poorly compatible with virus spikes, resulting in low neutralizing activity [35]. Although it has been more than a decade since the clinical trials were carried out, no progress has occurred for a long time.

Human mAb b12, which targets CD4bs of the gp120, could neutralize diverse HIV-1 primary isolates and fully protects hu-PBL-SCID mice from HIV-1 infection in vivo [36,37]. Interestingly, b12 Fab exerts inhibitory activity upon entry of the virus into cells. Therefore, b12 is thought to have a dual role, acting before and after infection [38]. Subsequently, the structure of b12 and Env was extensively studied, providing a basis for epitope studies of other bNAbs [39-41].

The gp120 CD4bs-Targeting Proteins

The binding of gp120 to CD4 plays a key role in the first step of viral entry. Soluble CD4 (sCD4), which contained four extracellular immunoglobulin homology domains (T4), can compete with the CD4 receptor for ligand and was the earliest candidate to be considered for development into potential anti-HIV drugs [42]. It was found that the first two extracellular domains (D1D2) could also simulate CD4 receptor binding to gp120 [43]. Then a series of antiviral tests were carried out in cells, animal models and clinical trials [44-46]. Results showed that sCD4 had high anti-HIV-1 activity in vitro and in vivo $[47,48]$. However, the half-life of sCD4 was relatively short. In some patients, the virus rebounded quickly and showed no evident treatment effects [44-46]. In addition, sCD4, at low concentrations, could enhance the infection of some clinical strains, possibly because the binding of sCD4 to HIV-1 gp120 results in the exposure of CoRbs, making it easy for the virus to infect neighboring cells $[49,50]$. These drawbacks greatly reduced the clinical applications of sCD4. In order to block the interaction between gp120 and the CD4 receptor in a more effective way, PRO-542, which contained the binding domain of CD4 (D1D2) and an IgG2 scaffold without the VH and VL domains, was designed [51,52]. As expected, PRO-542 interrupted CD4 binding with gp120 by mimicking the CD4 receptor and enhancing peptide valence and flexibility. Furthermore, it possessed broad neutralizing activity against primary HIV-1 isolates in vitro, and could decrease the viral load in murine models $[53,54]$. Compared to sCD4, PRO-542 bound with more avidity to virions and had a long half-life of 3-4 days in vivo. A Phase II single-dose study showed that PRO 542 caused an $80 \%$ response rate and that viral load was significantly reduced for several weeks post-treatment. However, intravenous administration and drug cost may be obstacles to clinical use [51,55]. Some smaller forms of sCD4 that only contain the D1 domain were designed based on the crystal structure of CD4 and gp120. However, they were very unstable in neutral environment and had lower affinity with gp120 than D1D2 [56]. Recently, using the power of a large phage display library and error-prone PCR 
technology, Dr. Dimitrov and colleagues identified two stable D1 mutants (mD1.1 and mD1.2), which could be expressed abundantly in E. coli, with high solubility and stability in neutral environment. In vitro antiviral experiments displayed that mD1.1 and mD1.2 could inhibit multiple HIV-1 strains at low nM level. They not only exhibited lower binding with human blood cell lines, but also resisted trypsin digestion and human serum degradation [57]. This group also identified an mD1.2 mutant with A55V mutation, mD1.22, from the phage display library, which exhibited better lytic expression, thermostability, specificity and neutralizing activity than mD1.2 [58]. Subsequently, they generated several bifunctional multivalent proteins $(2 \mathrm{Dm} 2 \mathrm{~m}, 4 \mathrm{Dm} 2 \mathrm{~m}$ and $6 \mathrm{Dm} 2 \mathrm{~m})$ by linking $\mathrm{mD} 1.22$ with a gp120 CoRbs-targeting neutralizing antibody domain (m36.4) and human IgG1 Fc [58]. Because these fusion proteins target both the CD4bs and CoRbs, they exhibited broadly cross-reactive and exceptionally potent neutralizing activity, about $10-, 50-$, and 200 -fold more potent than the bNAb VRC01, T20, and CD4-Ig, respectively. Furthermore, they have shown higher stability and specificity and a lower aggregation propensity than CD4-Ig. Later, they constructed a 4Dm2m mutant with prolonged half-life in mouse serum [59]. Most recently, we have tested the anti-HIV-1 activity of $4 \mathrm{Dm} 2 \mathrm{~m}$ in combination with several currently used ARDs, including Zidovudine (NRTI), Efavirenz (NNRTI), or Saquinavir (protease inhibitor), and with the gp41-targeting peptides, including T20, T2635, or SFT. We found that all these combinations exhibited synergistic anti-HIV-1 activity against infection by laboratory-adapted and primary HIV-1 strains, including those resistant to NRTIs and peptide-based HIV-1 entry inhibitors [60]. Application of these combinations are expected to reduce the dose of $4 \mathrm{Dm} 2 \mathrm{~m}$ and the ARDs tested, thereby reducing treatment costs and cytotoxicity.

The gp120 CD4bs-Targeting Peptides

Based on the $\beta$-hairpin region of a short scorpion toxin, scyllatoxin, and CDR2-like loop of CD4, CD4M9, a 28 amino acid peptide mimicking CD4 was synthesized [61]. The Phe-43 pocket of gp120 is a conserved and hydrophobic pocket, which binds to the CD4 receptor. CD4M9 can bind to the conserved CD4-binding pocket and thus interfere with CD4-gp120 interactions. With five additional mutations, CD4M9 was shown to bind the Phe-43 pocket of gp120 with nM affinity, effectively inhibiting infection of HIV-1 laboratory-adapted strains [61-63]. The characteristics of CD4M9 and its binding gp120 have been studied. Like sCD4, CD4M9 can induce a conformational change of gp120 after its binding to gp120, exposing the binding epitopes of antibody 17b and FabX5, both of which are CD4-induced (CD4i) epitopes, which overlap the CoRbs. Therefore, binding of CD4M9 to gp120 could block binding of gp120 to coreceptor [64]. To optimize interaction with gp120, a 27 amino acid CD4 mimetic peptide, CD4M33, was designed with a CD4-like affinity to HIV-1 Env. It inhibits HIV-1 activity more efficiently than sCD4 and is effective against sCD4-resistant strains [65]. CD4M47, a derivative of CD4M33, has a neutralizing profile similar to that of CD4M33, but without significant improvement in activity [66].

M48 is a CD4 mimetic that targets the gp120 Phe-43 pocket [66], and its derivatives include M48U1-M48U14 [67]. M48U1, composed of 27 amino acids, has been extensively studied. It inhibits the HIV-1 pseudovirus at the pM or nM level [68] and can induce gp120 shedding at high concentrations, resulting in a reduction in new viral particles released by infected cells [69]. In addition, M48U1 is resistant to rhesus macaque infection SHIV [70] and is expected to act as a microbicide to prevent sexual transmission of HIV-1.

Using phage-displayed 12-mer peptide libraries, a novel peptide, G1, which inhibits the interaction between HIV-1 gp120 and CD4 was found. The IC50 for inhibition of the interaction between gp120 and CD4 is about $50 \mu \mathrm{M}$. NMR structural analysis showed G1 to be capable of forming a tight ring structure upon binding to gp120. The follow-up results showed that six amino acids (PSFDLQ called G1-6) in the middle of G1 play a crucial role in its activity. This hexametric linear peptide exhibited about 10-fold lower IC50 of $6 \mu \mathrm{M}$ than G1. Furthermore, adding cysteines on G1-6 at both ends let it form a ring, and the G1-c peptide (CQPSFDLQC) showed an even lower IC50 of about $1 \mu \mathrm{M}$ [71]. However, in the current literature, we could find no related studies reporting on the inhibitory activity 
of these peptides on cell-cell fusion, as well as a variety of HIV-1 strains, which, therefore, begs for further assessment.

Using random phage libraries of 12-mer, 7-mer, and cyclin 9-mer peptides, Ferrer and Harrison screened a 12-mer peptide, 12p1, that interacted with gp120 and inhibited the binding of gp120 from three different HIV strains to four-domain soluble CD4 [72]. Interestingly, it could also inhibit the interaction of gp120 and $\mathrm{mAb} 17 \mathrm{~b}$. Analysis of the $12 \mathrm{p} 1$ binding site suggested that the inhibitory activity of $12 \mathrm{p} 1$ to mutant viruses was reduced significantly by the mutation of Arg476, Lys97 or Glu102 of gp120. These gp120 residues make no contact CD4, but all are located near the CD4bs. These results suggested that the binding mechanisms of CD4 and 12p1 are different. It is possible that $12 \mathrm{p} 1$ interacts with and stabilizes an unliganded gp120, rather than the activated one by CD4, resulting in the inability of gp120 to interact with its receptors [73]. Subsequently, the interaction between 12p1 and gp120 was studied by STD NMR, and after models of $12 \mathrm{p} 1$ binding to gp120 in different states were proposed, the subtle difference was revealed [74]. Its derivatives showed inhibitory activity at the $\mathrm{nM}$ level in viral infection experiments (IC50=156 nM for R5 Bal strain) [75]. However, compared to sCD4, further optimization still needs to be done. In addition, a common drawback among CD4M9, G1 and 12p1 is the human body. That is, modified exogenous proteins are likely to induce specific antibodies which would have a negative impact on the inhibitory activity, or half-life, limiting their clinical use as therapeutic agents.

\subsubsection{Antibodies, Recombinant Proteins and Peptides Targeting gp120 Coreceptor-Binding} Site (CoRbs)

The gp120 CoRbs-Targeting Antibodies

Some HIV-neutralizing antibodies can recognize the epitope in gp120 induced by CD4 binding. This CD4i epitope generally overlaps with CoRbs on gp120 [76]. Therefore, most of these antibodies inhibit the binding of gp120 to the coreceptor. M36 is a single-stranded human antibody domain targeting gp120 CD4i obtained by screening human antibody variable domain libraries using HIV-1 Env [77]. Later, M36 mutants with higher neutralizing activity were screened out. The antibody has a small molecular weight $(15 \mathrm{KDa})$ with a short half-life and is used to construct a bimolecular fusion protein [78].

Several other well-known CD4i-specific antibodies have been reported, include 17b [79,80], 48d, 47e, 412d, E51, 16C, 23e, 411g, C12, Sb1, X5 and m16 [81]. The N-terminus of the coreceptor CCR5 is sulfated tyrosine. Some CD4i-specific antibodies containing sulfated tyrosine, including E51 [82], 412d [83] and 47e [84], have shown stronger gp120-binding affinity than those without sulfated tyrosine.

The gp120 CoRbs-Targeting Peptides

Two sulfated tyrosines (Tys173, Tys177) in the V2 loop of gp120 stabilize the intramolecular interaction of the V2 and V3 loops of gp120. Studies have found that the Tys177 sulfated peptide $\mathrm{pV} 2 \alpha$-Tys (amino acids 168-185) derived from the V2 loop can serve as a structural and functional mimetic of the N-terminus of CCR5, acting directly on the CoRbs on the gp120 V3 loop in a CD4-dependent manner, thereby blocking the binding of gp120 to the coreceptor and inhibiting HIV-1 infection [85]. pCCR5-Tys is a Tys-sulfated CCR5 N-terminal mimetic peptide that targets the CCR5 binding site on gp120 and effectively inhibits HIV- 1 infection of CCR $5^{+}$cells [86]. It has been shown that $\mathrm{pV} 2 \alpha$-Tys competes with pCCR5-Tys for binding to gp120, establishing an intermolecular interaction with the CoRbs in the V3 loop [85]. Unlike pCCR5-Tys, pV2 $\alpha$-Tys is not restricted by HIV-1 coreceptor tropism and has a broad spectrum of anti-HIV-1 activity. Moreover, pE51 is a sulfated peptide derived from the CDR 3 region of the CD4i antibody E51, which inhibits the binding of HIV-1 to the CCR coreceptor in a CD4-independent manner [87]. However, the inhibitory activity of these peptides is at the $\mu \mathrm{M}$ level, and further optimization is needed. 


\subsubsection{Antibodies or Recombinant Proteins Targeting gp120 Variable Loops and/or Glycan}

Antibodies Targeting gp120 Variable Loops and/or Glycan

PG9 and PG16 are similarly potent mAbs isolated from HIV-1 patients. Compared to the earlier gp120-targeting bNAb 2G12 [88], both have higher neutralizing activity and broad spectrum in 162 different subtypes of HIV-1 pseudovirus neutralization experiments [89]. The neutralizing epitopes of PG9 and PG16 mainly depend on the specific position of the N-linked glycosylation on the gp120 V1-V3 loop and the glycan profile [90]. However, HIV-1 has gradually increased resistance to the bNAbs, such as 2G12, PG9 and PG16, during the virus evolution process [91,92]. Studies have shown that PG9 or PG16 and CD4-targeting monoclonal antibody ibalizumab (iMab) were constructed as bispecific antibodies, which not only have high inhibitory activity, but also effectively inhibited infection by PG9- and PG16-resistant strains [93]. Recent studies have found that 2G12, PG9 and PG16 can efficiently recognize HIV-1-infected CD4 T cells and induce CD4 T cell clearance by antibody-dependent complement-mediated lysis (ADCML) and antibody-dependent cell-mediated cytotoxicity (ADCC). Therefore, these bNAbs can be used in combinations to maximize the clearance of HIV-infected cells for HIV cure [94].

The four bNAbs, $\mathrm{CH} 01$ to $\mathrm{CH} 04$, are derived from the same clonal lineage isolated from HIV-1-infected individuals. They, which recognize conformational epitopes similar to PG9 and PG16 epitopes on gp120 V2/V3, can mainly neutralize tier 2, rather than tier 1, primary isolates. CH03 has the strongest neutralizing activity with mean and median IC50 of 2.4 and $0.46 \mu \mathrm{g} / \mathrm{mL}$, respectively, against 91 HIV-1 primary isolates [95].

The PGT class of antibodies includes PGT121-123, PGT125-128, PGT130-131, PGT135-137, and PGT141-145 [96], which were isolated from elite controllers infected with HIV-1. These antibodies exhibited different HIV-1 neutralizing activities. PGT128 was the most potent bNAb; it had an IC50 of $0.02 \mu \mathrm{g} / \mathrm{mL}$ against 162 different subtypes of HIV-1 pseudovirus [96]. However, later studies found that circulating HIV-1 clade C in patients could escape the neutralization of PGT128 with N332 glycan specificity [97]. The crystal structure of the PGT128-gp120 complex indicates that PGT128 binds to a shorter $\beta$-sheet within the gp120 V3 loop. Since the V3 loop of gp120 is highly variable and easily masked by the HIV-1 Env trimer spike, the role of this antibody in humoral immunity may be limited [96].

10-1074 is a clonal variant of PGT 121 targeting the gp120 V3 loop isolated from a patient infected with subtype A HIV-1 [98,99]. The bNAb 10-1074 has neutralizing activity in vitro and in vivo [100]. Although a strain resistant to 10-1074 was found in phase I clinical trial [100], the combination of 10-1074 and 3BNC117 resulted in long-term effective inhibition of viral load in patients, and no resistant strains were found [101,102].

\section{Recombinant Proteins Targeting gp120 Variable Loops and/or Glycan}

Some lectins have been found to interact with gp120 resulting in interference with the binding of gp120 to the CD4 receptor, thereby demonstrating anti-HIV-1 activity. However, their specific antiviral mechanisms of action are still unclear; nonetheless, such mechanisms may interact with glycans on gp120 to exert antiviral effects [103]. Cyanovirin-N (CV-N) is an 11KDa protein derived from cyanobacteria [104]. It irreversibly inactivates HIV-1/2 and SIV at low nM levels. Griffithsin (GRFT) is a 12.7KD protein derived from red algae [105], and it has been shown to inhibit HIV-1 infection and Env-mediated cell-cell fusion at the pM level. Deletion and rearrangement of glycosylation sites on gp120 may confer tolerance to CV-N and GRFT [106,107]. However, CV-N and GRFT can be amply expressed in E. coli with low cytotoxicity; therefore, both are expected to be further developed as microbicides. Recently, several legume lectins, including (ConBr) Canavalia brasiliensis lectin, (ConM) Canavalia maritima lectin, (DLasiL) Dioclea lasiocarpa lectin, (DScler L) Dioclea sclerocarpa lectin and (HHA) Hyppeastrum hybrid agglutinin all showed a low nM level of HIV-1 inhibitory activity and thus deserve further study [108]. 


\section{Protein-and Peptide-Based HIV Entry Inhibitors Targeting gp41}

It is quite effective to terminate the whole fusion process and inhibit virus invasion by blocking any single step in the fusion process. The transmembrane subunit gp41 is one of the most important targets for the design of fusion inhibitors because of its role in the viral-cell membrane fusion process. The gp41 extracellular domain consists of the N-terminal FP, the NHR, the loop region, the CHR, and the MPER (Figure 2A). The 6HB, a coiled-coil structure formed by three inner NHRs and three anti-parallel CHRs, is the core molecule gp41 function (Figure 1d) [9]. In addition, FP and MPER domains are also attractive targets, since several important anti-HIV peptides and neutralizing antibodies targeting these domains have been reported, as described below.

\subsection{Antibodies or Recombinant Proteins Targeting gp41}

\subsubsection{Antibodies and Recombinant Proteins Targeting gp41 NHR}

The gp41 NHR-Targeting Antibodies

D5 is a human-derived scFv screened from a phage display library. It targets the NHR pocket-binding region of gp41 and blocks infection by different HIV isolates [109,110]. In addition, the attachment of D5 to cholesterol increases its membrane binding and antiviral activity, consistent with the results obtained by linking cholesterol to anti-HIV peptides and other mAbs [111-113]. MAb HK20 is isolated from HIV-infected individuals whose epitope covers the conserved hydrophobic pocket region in NHR. Surprisingly, the neutralization activity of HK20 on different target cells has varied greatly [114]. Subsequently, the crystal structures of HK20 and D5 combined with 5-helix were revealed. The combination of HK20 and D5 with NHR epitopes at different angles may allow HK20 to exhibit higher neutralizing activity and broad profile [115].

Other antibodies targeting NHR are rabbit scFv 8K8 and human Fab DN9, the epitopes of which partially overlap with the epitope of D5 and exhibit moderate neutralizing activity against different HIV strains [116]. In addition, the epitope of murine monoclonal antibody 1 G12 may coincide with the target of T20 because it blocks the anti-fusion effect of T20 and binds to NHR-derived peptide [110].

The gp41 NHR-Targeting Peptides

C52L is a 55 amino acid recombinant peptide containing the entire T20 and C34 sequences with higher helicity and binding ability to NHR. It showed inhibitory activity similar to that of C34 in vitro, which was much better than T20. More importantly, C52L and its derivatives could be highly expressed in the E. coli system, up to $85 \mathrm{mg}-145 \mathrm{mg}$ per liter of culture. Although it needs further optimization, this is still exciting news for future low cost and large-scale production [117]. Our group has also designed a series of recombinant CHR-peptide fusion inhibitors, such as C66 (residues 610-675) and C72 (residues 610-681). They were not reported because of their low inhibitory activities (below that of T20). Interestingly, we found that the purification methods of the recombinant peptides were closely related to their anti-HIV activities. For example, CHR-peptide purified by GST-PreScission Protease system had the lowest activity, which may be caused by many reasons, such as the additional protease cleavage sites and the detergent in the elution buffer.

TLT35 was designed by linking T20 to T1144 via a flexible linker [118]. This covalent attachment greatly enhances the enrichment of T20 and T1144 around the target, showing high activity and broad spectrum. Moreover, both T20 and T1144 fragments in TLT35 form a high $\alpha$-helical structure, which enables TLT35 to be expressed in E. coli and has good resistance to protease.

\subsubsection{Antibodies and Recombinant Proteins Targeting gp41 CHR}

CHR-specific antibodies include murine monoclonal antibodies D40, D17, D50 [119] and FC-1, which exhibit different neutralizing activities against various HIV isolates [120]. In addition, human monoclonal antibodies HGF24 [114] and A2 were also found to specifically target the pocket-binding 
domain of gp41 CHR when CHRs maintain in the trimer conformation [121]. However, the neutralizing titers of these antibodies have not been reported, likely because of their lower neutralizing activity.

\section{The gp41 CHR-Targeting Proteins}

The recombinant protein NCCG-gp41 consists of N35 (residues 546-580)-N34 (residues 546-579)-SGGRGG-C28 (residues 628-655), wherein the 576-578 residues of N35 are replaced by CCG, resulting in the formation of a trimer [122]. The NCCG-gp41 trimer exhibits potent anti-HIV activity in vitro, and its IC50 is at low nM for HIV-1 Env-mediated cell-cell fusion.

Our groups have successfully designed and produced recombinant chimera protein HIV-1 fusion inhibitors, including N36Fd, N28Fd, and ccN28Fd. N28Fd and N36Fd were designed by fusing the NHR-peptides with a trimerized motif foldon (27 residues form T4 phage fibritin, highly hydrophilic and highly trimerized) which served to stabilize the chimeric trimer in physiological condition in order to allow the NHR-peptide part to efficiently interact with gp41 CHR [123] and were expressed as recombinant proteins in E. coli. N28Fd is both highly soluble and is able to form a trimeric conformation in neutral buffer. The viral inhibition activity of N28Fd is 135-fold more potent than that of N28 peptide, 15-fold more potent than that of N36 peptide and quite similar to T20 (low nM range). However, $\mathrm{N} 28 \mathrm{Fd}$ is sensitive to proteolytic enzymes and low $\mathrm{pH}$ environments. The addition of two cysteines at its $\mathrm{N}$-terminus constitutes ccN28Fd, which is resistant to heat, pepsin and proteinase $\mathrm{K}$. ccN28Fd is approximately 20-fold more active than N28Fd in inhibiting HIV-1 IIIB and Bal infection [124]. In addition, since the inhibitory activity of $\mathrm{ccN} 28 \mathrm{Fd}$ is not affected by semen and vaginal secretions, it also shows promise for the development of microbicides.

\subsubsection{Antibodies and Recombinant Proteins Targeting NHR/CHR Complex}

A variety of antibodies targeting NHR/CHR complex were found, such as human monoclonal antibodies Fab-d [125], 50-69 [126], 126-7 [127], murine monoclonal antibodies NC-1 [128], 2G8 and 9F2 [129]. However, most of them cannot neutralize HIV at physiological temperature $\left(37^{\circ} \mathrm{C}\right)[125,128,129]$. Interestingly, some antibodies inhibit HIV Env-mediated cell-cell membrane fusion at subtemperature $\left(31.5^{\circ} \mathrm{C}\right)$ [129]. It is believed that membrane fusion at physiological temperatures may be a rapid process and that steric hindrance hinders antibody binding, while molecular dynamics at subtemperature slows, prolonging the fusion process and allowing antibodies to be active $[10,129,130]$.

We used the yeast two-hybrid technology to screen natural HIV protein inhibitors and finally obtained peptide P20, which is derived from human TNNI3K-like protein. Its derivative P20-A could inhibit a broad range of HIV-1 strains at low $\mu \mathrm{M}$ level, including T20-resistant strains. Interestingly, this peptide bound to $6 \mathrm{HB}$ and did not block the formation of $6 \mathrm{HB}$. It suggested that the membrane fusion process was more complicated than we thought. The fusion did not complete immediately after $6 \mathrm{HB}$ formation. A series of previously unknown molecular events very likely takes place [131]. Miyauchi provided compelling evidence to show that HIV enters cells primarily by endocytosis [132], which may prove a similar view: that the virus and target cell membrane do not start to fuse immediately after gp41 changes conformation. Of course, this view is currently controversial.

In addition, using recombinant soluble gp41 (rsgp41) as bait, the human bone marrow cDNA library was screened by the yeast two-hybrid technique, and the endocytic protein POB1 binding to rsgp41 was identified. Further analysis revealed that C60 (residues 462-521), derived from the C-terminus of POB1 [133], is effective in inhibiting HIV-1 infection. Intensive research has found that it inhibits HIV-1-mediated membrane fusion, primarily by interacting with residues in the NHR exposed to the $6 \mathrm{HB}$ surface, but not blocking the formation of $6 \mathrm{HB}$. In addition, POB1 mediates HIV-1 entry into epidermal cell A431, which lacks the CD4 receptor $\left(\mathrm{CD}^{-}\right)$, revealing that HIV-1 can infect $\mathrm{CD}^{-}$ cells in a non-CD4-dependent manner [134]. Although C60 inhibits the activity of HIV-1 infection at low $\mu \mathrm{M}$ levels, it can be used as a probe to study the membrane fusion mechanism of HIV-1 and as a lead to develop HIV entry inhibitors targeting 6HB. 


\subsubsection{Antibodies and Recombinant Proteins Targeting gp41 MPER}

The gp41 MPER-Targeting Antibodies

The HIV-1 gp41 MPER is a highly conserved region (Figure 2B), and a variety of human monoclonal antibodies have been found to target different epitopes in MPER and neutralize different subtypes of HIV-1. Therefore, MPER is also one of the important targets for HIV-1 vaccine design [135]. 2F5 neutralizes multiple HIV-1 laboratory-adapted and clinical strains and exerts antiviral activity by interacting with linear epitopes formed by the ELDKWA (residues 662-667) sequence in the gp41 MPER region [136].

Subsequently, another human monoclonal antibody, 4E10, was also obtained. It specifically recognizes the relatively conserved tryptophan-rich linear epitope (residues 671-676) located in the MPER. Although 4E10 has broad-spectrum neutralizing activity, it is exceptional for some strains of subtype B and subtype D. In addition, 2F5 and 4E10 have autoreactivity and can bind to the phospholipid bilayer of the MPER region [137], which is believed to cause some toxic side effects.

$10 \mathrm{E} 8$ is a bNAb derived from an HIV-1 patient whose epitope contains the residues of the transmembrane region (TM) and the entire MPER of gp41. Unlike 2F5 and 4E10, 10E8 has higher HIV-1 neutralizing activity and has no specific reactivity to self-antigens [138]. By identifying the hydrophobic region on 10E8 and optimizing its heavy and light chains, the 10E8 mutant 10E8v4 was successfully produced [139], which not only has higher solubility but also retains neutralization activity and profile similar to that of 10E8. Using CrossMab technology, some researchers have constructed a bispecific antibody library and screened out an excellent and broad-spectrum HIV-1 neutralizing antibody 10E8v2.0/iMab, which neutralizes $118 \mathrm{HIV}-1$ pseudoviruses with IC50 as low as $0.002 \mu \mathrm{g} / \mathrm{mL}$ [140]. In a humanized mouse model, 10E8V2.0/iMab has a positive effect on the prevention and treatment of HIV-1 infection. Studies have shown that the main reason for the high neutralizing activity of 10E8v2.0/iMab is the ibalizumab (iMab) component which can guide 10E8 v2.0 enrichment at the site where the fusion occurs, enabling the antibody to exert neutralizing activity more efficiently. 10E8.4/iMab with higher solubility and stability is obtained by introducing some hydrophilic amino acid mutations into 10E8v2.0/iMab [141]. Moreover, the in vitro and in vivo antiviral activity of 10E8.4/iMab was slightly higher than that of 10E8.2/iMab.

\subsection{Peptides Targeting gp41}

\subsubsection{Peptides Targeting gp41 FP}

Kirchhoff's group used a comprehensive peptide library generated from human hemofiltrate to make a large-scale screen, and they obtained peptide VIRIP derived from a human natural protein $\alpha 1$-antitrypsin. Instead of interacting with gp41 NHR or CHR, this peptide bound to gp41 FP. Its derivative, VIR-576, could inhibit infection of the diverse HIV-1 strains, including those resistant to T20 in vitro at low $\mu \mathrm{M}$ level [142]. Later, VIRIP was used to construct bispecific molecules with higher inhibitory activity [143]. It implies that other domains on gp41 may also serve might be designed as a drug targets for to development of novel HIV entry inhibitors. It also provided important details about the membrane fusion process, in particular, whether FP domain was exposed outside when gp120 made its conformational changes. VIRIP can also be used a molecule probe to study the function of the gp41 FP in membrane fusion process.

At present, it is reported that co-infection of GBV-C (a lymphotropic virus that replicates in primary T and B lymphocytes) with HIV-1 is beneficial to patients with HIV-1 disease [144-146], but different views prevail [147]. For safety reasons, the researchers used GBV-C proteins, such as E1 and E2, to study their anti-HIV-1 activity, and they found that some peptides derived from E1 or E2 may inhibit HIV-1 infection by interacting with HIV-1 FP [148-153]. The 18-amino acid peptide E1P47 was screened from the E1 protein overlapping peptide library, and it has a broad spectrum of HIV-1 
inhibitory activity [154]. Peptide P6-2 is derived from the E2 protein, and its inhibitory activity against the original isolate is comparable to that of VIR-576 [151].

\subsubsection{Peptides Targeting gp 41 NHR}

For many enveloped viruses, $6 \mathrm{HB}$ is an important target for the design of fusion inhibitors [155-158]. In 1997, using crystallography, Chan's group proved that NHR and CHR strongly interacted with each other to form the coiled-coil six helix bundle in vitro. This detailed structure explained how NHRand CHR-derived peptides could inhibit viral-cell fusion effectively. More specifically, the synthetic peptide bound to the fusion intermediates and occupied the position, preventing natural NHR/CHR to form the active $6 \mathrm{HB}$, followed by terminating membrane fusion. This laid the foundation for the design of fusion inhibitors [159-165]. Two representative peptides, C34 (CHR-peptide) and N36 (NHR-peptide) [166], form a six-helix complex in vitro with the N36 trimer as the core and the three C34 peptides in anti-parallel, similar to native $6 \mathrm{HB}$. Since then, this in vitro six-helix complex has been thought to mimic native $6 \mathrm{HB}$ and is therefore used to screen for fusion inhibitors that target NHR or CHR [167]. Although a number of peptides have been designed based on this classical in vitro 6HB model, it only considers the position and orientation of the CHR backbone, thus bringing limitations to the optimization of inhibitors. A modified new model NHR-CHR-NHR was proposed, in which more CHR residues were found (assistant binding sites, $\beta$ ) to interact with NHR (Figure 3). Some CHR-peptides based on the new model show various HIV-1 inhibitory activities, demonstrating the importance of the assistant binding sites [168]. Currently, most peptide fusion inhibitors are derived from gp41 NHR and CHR, especially the CHR domain. Most of the amino acids of NHR are very important for viral infection, and it is a popular research target for CHR-peptides [169]. In fact, CHR-peptides are more effective than other peptides in HIV inhibition. Here is a summary of the amino acid sequences of CHR-peptides and their inhibition of cell-cell fusion activity (Figure 3). However, we should also consider their biochemical properties [170,171], such as solubility and stability [172].

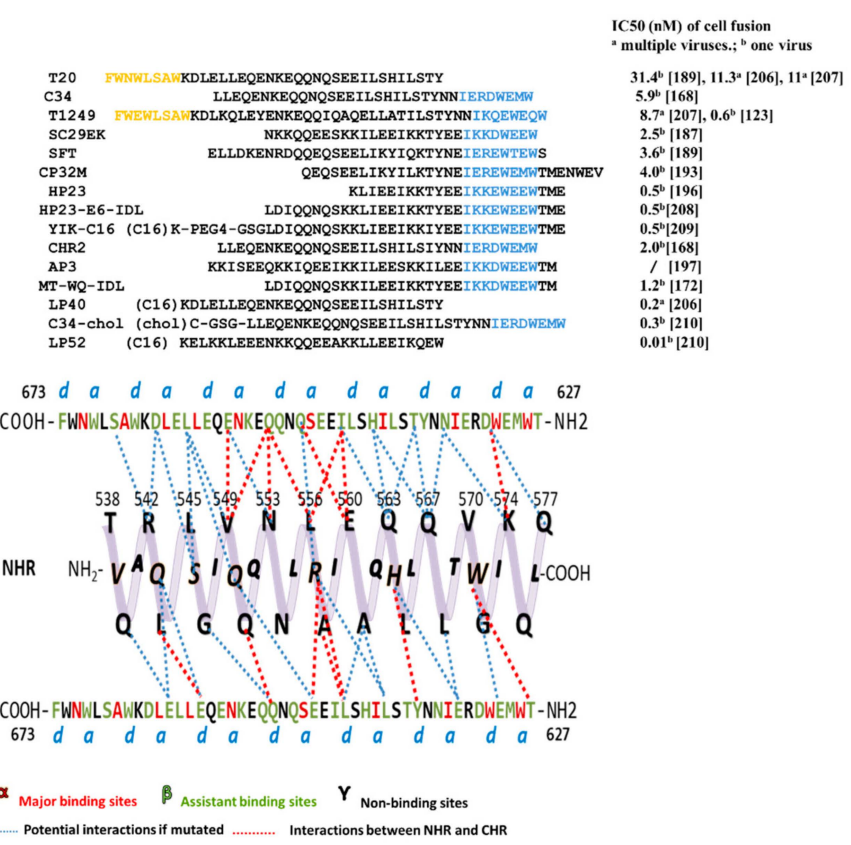

Figure 3. Tripartite model of gp41 N-terminal heptad repeats (NHR) with side view and C-terminal heptad repeats (CHR)-derived peptides. Above, the sequences of CHR-peptides targeting NHR. Residues represent pocket-binding domain and lipid- binding domain marked in blue and orange, respectively. Below, residues of CHR are divided into three groups: major binding sites $\alpha$, assistant binding sites $\beta$, and non-binding sites $\gamma$. The potential interaction, or interaction, between CHR and NHR is shown in blue or red dashed lines. 


\section{The First Generation CHR-Peptides}

The first generation CHR-peptides consist of three peptides derived from the HIV-1 gp41 CHR domain, including SJ-2176 (residues 630-659), DP-178, which was named T20 later (residues 638-673), and C34 (residues 628-661), which were reported by Jiang et al. at the New York Blood Center in 1993 [163,164], by Wild et al. at the Duke University 1994 [165], and by Lu et al. at MIT in 1995 [166], respectively. New York Blood Center filed the patent on SJ-2176 (US Patent 5,444,044) on March 26, 1992 (issued on August 22, 1995), while Duke University filed the patent on T20 (US Patent 5,464,933) on June 7, 1993 (issued on November 7, 1995). The group at Duke University established a pharmaceutical company named Trimeris, Inc. to develop T20 as a fusion inhibitor-based anti-HIV drug. As T20 has 22 amino acids overlapping SJ-2176, Trimeris had to license New York Blood Center's patent in 1997 for the development of T20.

T20 (enfuvirtide) was approved by the U.S. FDA in 2003 as the first HIV fusion inhibitor-based anti-HIV drug for clinical use to treat HIV-infected patients who have failed to response to current ARDs [173-175]. However, its clinical application is limited because of its low potency (about 10-fold less potent than C34) and short half-life (about $2 \mathrm{~h}$ ), thus requiring subcutaneous injections twice daily at a dose of $90 \mathrm{mg}$ and causing severe injection site reactions [176,177]. Our previous studies have shown that unlike $\mathrm{C} 34$ that contains a pocket-binding sequence (PBD), which is critical for the interaction between a CHR-peptide and viral gp41 NHR to form stable 6HB and inhibition of HIV fusion, T20 lacks PBD and thus cannot interact with viral gp41 NHR as effectively as C34 to block HIV infection $[178,179]$. However, T20 contains a tryptophan-rich motif (TRM) or lipid-binding region (LBD). We thus believed that T20 needs the LBD to interact with target cell membrane to enhance its interaction with the viral NHR domain $[178,179]$. Zhang et al. have shown that T20 is able to interact with N39 peptide, which contains partial sequences of the NHR domain and the fusion peptide proximal region (FPPR), the downstream region of the C-terminus of the FP, to form 6HB [180]. Most recently, we have demonstrated that T20 can inhibit the formation of the native 6HB on HIV-1-infected cells, but only in the early, not the late stage of fusion, and the interaction with FPPR may play an important role in its inhibitory activity. Based on this newly clarified mechanism of action of T20, we designed a new peptide, T20-SF, by adding an additional TRM to the C-terminus of T20 and found that T20-SF exhibited significantly improved anti-HIV-1 activity because it targets the triple sites in gp41, including NHR, FPPR, and FP [181].

\section{The Second Generation CHR-Peptides}

The second generation CHR-peptides are the mutant peptides of T20 or C34 with anti-HIV-1 activity about 10- to 20-fold more potent than T20, such as SC34 and its analogs, T1249 and T1144, sifuvirtide and albuvirtide.

A series of CHR-peptide mutants has been designed to improve their solubility, NHR-binding affinity, antiviral potency, or half-lives [182-184]. Fujii's group modified the C34-like peptide to increase its solubility and enhance its interaction with NHR by introducing EE-KK double salt-bridge. The first designed peptides, SC34 and SC35EK, showed activity similar to that of C34, while they interacted with gp41 NHR more strongly and were more soluble than C34, thus being better drug candidates for further development [182]. SC35EK was further shortened to SC29EK and kept similar HIV-1 inhibitory potency [185-187]. The same strategy was applied to T20 and resulted in T20EK, with 10-fold potent increase compared with T20. It is also effective against T20-resistant HIV-1 isolates [186].

T1249 and T1144 were developed by Trimeris, Inc., in a hope to replace T20 [179,182-184]. T1249 contains C34's PBD and T20's LBD. Although T1249 had enhanced anti-HIV-1 activity against T20-resistant HIV-1 strains, its Phase II clinical trial was terminated because of the reports of side effects [161]. T1144 was designed based on the sequence of C38 peptide (residues 626-663). In vitro, it shows stronger antiviral activity than T1249 against infection of divergent HIV-1 strains, including those resistant to T20 [188]. In particular, it maintains a stable $\alpha$-helic trimeric structure (up to $97 \%$ ) in neutral buffer. These characteristics contribute to its enhanced anti-HIV potency and stability [182]. 
However, some studies have proved that certain CHR-peptides with high helicity (100\%) and stable binding with NHR (Tm value $>100{ }^{\circ} \mathrm{C}$ ) show little anti-HIV activity [184]. Therefore, the appropriate affinity with NHR and the proper helicity may lead to the highest anti-HIV activity.

Sifuvirtide is a novel peptide inhibitor developed by Fusogen, Inc. [189]. Its sequence is derived from C34 with some mutations, and the spiral property is enhanced. Similar to C34, sifuvirtide strongly bound to NHR-peptide and significantly inhibited 6HB formation [190]. It also has a more potent anti-HIV activity in vitro than T20 [189], especially to T20-resistant HIV-1 strains. Sifuvirtide has successfully passed Phase I and II clinical trials in China. Also, the efficacy of sifuvirtide in monotherapy at $20 \mathrm{mg}$ once daily is equivalent to that of enfuvirtide at $90 \mathrm{mg}$ twice daily (http://www.fusogen.com). However, its further development has been terminated with unknown reasons.

According to the crystal structure of the complex formed by C34 and NHR-peptide, FB006 was designed by substituting three residues in C34 which were not bound to the NHR-peptide with Lys and Glu. Conventional peptide inhibitors are susceptible to protease degradation and therefore have a short half-life in vivo, but their binding to serum albumin prolongs their half-life in vivo [191]. Conserved Cys residues occur in different species of albumin (Cys34 in humans), and Cys only has the free sulfhydryl group. In order to bind the peptide to the thiol group in albumin, different residues of FB006 were modified with maleimidopropionic acid (MPA) to obtain corresponding modified peptides. These modified peptides were bound to human serum albumin (HSA) and tested for their anti-HIV activity in vitro. FB006M obtained by chemical modification of the 13th residue of FB006 with MPA is not immunogenic. The half-life of FB006M in rhesus monkeys is more than 100h, which is about 10-fold longer than that of FB006 [192]. In clinical trials, FB006 (albuvirtide) administered intravenously with current ARDs once a week could effectively inhibit HIV-1 infection and reduce viral load. Therefore, it was approved by the China Food and Drug Administration (CFDA) for clinical use in 2018.

\section{The Third Generation CHR-Peptides}

The third generation CHR-peptides are the modified CHR-peptides with anti-HIV-1 activity more than 50-fold more potent than T20, including CHR-peptides containing MT-hook or IDL anchor, and lipopeptides.

\section{CHR-Peptides Containing MT-Hook}

He et al. have shown that the peptide CP32 (residues 621-652) exhibited more potent anti-HIV-1 activity than T20 and C34. Its derivative, CP32M, inhibits not only T20-resistant strains, but also C34-resistant strains $[193,194]$, providing a novel paradigm for the development of a new generation of entry inhibitors. Analysis of the crystal structure of $6 \mathrm{HB}$ formed by CP32 or CP32M, and NHR-peptide DP107 (T21) revealed that Met-626 and Thr-627 in CP32 can form a hook-like structure (called MT-hook), which can stabilize the interaction of CHR-peptide and the pocket-forming domain (PFD) of NHR, and significantly increase the inhibitory activity of CHR-peptide [190]. Therefore, MT-hook is widely used in the design of CHR-peptides. HP23, a 23-residue peptide, which contains MT-hook and PBD, has high binding stability and antiviral activity, including T20-resistant, or MT-SC22E-resistant strains [195,196]. Subsequently, the short peptide 2P23 containing the MT-hook and the HIV-2 sequence was designed. The highly stable helical peptide $2 \mathrm{P} 23$ has broad-spectrum inhibitory activity against different subtypes of HIV-1, including T20-resistant strains and HP23-resistant strains [195]. However, compared to HP23, 2P23 has low HIV-1 inhibitory activity. The CHR-peptides derived from gp41 CHR contain some natural sequences and may, therefore, crossreact with pre-existing antibodies in the serum of HIV patients. In order to avoid this phenomenon, we designed artificial peptides AP1 and AP2 and added MT-hook at the N-terminus of AP2 to stabilize the interaction with NHR to obtain AP3, which can fold into a single helix to interact with gp 41 NHR to prevent $6 \mathrm{HB}$ formation [197]. In addition, AP3 is superior to T20, AP1 and AP2 in antiviral activity, antiviral profile and pharmacological properties. Surprisingly, pre-existing antibodies in patients not only fail to recognize AP3, but also enhance its anti-HIV activity. This mechanism is still worth exploring. 


\section{CHR-Peptides Containing IDL Anchor}

Using a computer model to analyze the crystal structure of the NHR trimer, we found a shallow pocket at the N-terminus of the NHR (L544-V549), which was named the N-terminal hydrophobic pocket (NTHP). It consists of Leu544 and Ile548 of one NHR helix and Leu545 and Val549 residues of another NHR helix [172]. These residues are highly conserved among different HIV-1 strains, and we hypothesized that enhancing the binding of the CHR-peptide to NHR NTHP could increase its inhibitory activity. Therefore, we designed a series of long-chain hydrophobic residues at the C-terminus of CHR-peptide WQ (residues 628-653) to target NTHP. As expected, the newly designed peptide WQ-IDL was more active than T20 in inhibiting HIV-1 IIIB and Bal infection. Introducing the MT-hook at the N-terminus of WQ-IDL, we found that the activity of MT-WQ-IDL was further improved [172]. It may be that MT and IDL enhance the binding of WQ peptide to NHR PFD and NTHP, respectively [172]. Peptide WQ is also termed peptide CP. CP-IDL was coupled to N36 or N43 using the "SGGRGG" linker to form an N36-L6-CP-IDL or N43-L6-CP-IDL complex. The crystal structure indicates that the IDL tail can form two different conformations. One is alpha-helix (N36), and the other is a hook-like structure (N43), which exhibits a broader interaction with NHR [198].

\section{Lipidated CHR-Peptides}

It is widely believed that lipids in lipopeptides are able to anchor peptides to the cell membrane, resulting in elevated concentrations of peptides at the fusion site [199-202]. However, Klug et al. proposed a different mechanism of the sphinganine lipidated peptides, in which sphinganine and PBDK peptide, a 15-mer peptide derived from the pocket-binding domain of the gp 41 CHR region, jointly disrupt early and late events of membrane fusion [203]. Furthermore, lipopeptides exhibited prolonged half-life in vivo than unconjugated peptides, possibly because they can reversibly bind to proteins in serum $[163,188,204]$. He et al. modified HP23 and 2P23 with different lipids (e.g., fatty acids, cholesterol, sphingolipids). HP23 and 2P23 were conjugated to palmitic acid (C16), respectively, and the MT-linked methionine in HP23 was replaced with leucine to construct LP-11 and LP-19, which mainly targeted the PFD of gp41 NHR and inhibited different HIV-1 clinical isolates, including T20-resistant strains and HP23 or 2P23-resistant strains. In addition, LP-19 can effectively inhibit HIV-2 and SIV infection $[199,205]$. The same team then designed a series of lipopeptides, for example, to design LP40 by replacing the T20 C-terminal tryptophan-rich region (TRM) with C16. Interestingly, LP40 inhibits cell-cell fusion and pseudovirus entry activity complementary to LP-11, thus having a synergistic antiviral effect [206]. Similar to the LP40 design strategy, LP46 was constructed by replacing the T1249 C-terminal TRM with C16. LP46 has higher inhibitory activity than LP40, with IC50 values down to pM levels, and exhibits synergy with LP40 [207]. We previously designed the HP23-E6-IDL peptide and later introduced a single amino acid mutation and added palmitic acid to obtain YIK-C16 lipopeptide, which exhibits high antiviral activity and a long half-life [208,209]. LP52 is a 28 amino acid lipopeptide designed based on the analysis of the structure-activity relationship of LP40 and LP46. It does not contain PBD and TRM, but its C-terminus is coupled to C16. LP52 has a high gene barrier and a long half-life. It also inhibits a large number of HIV-1 isolates at low pM levels and also has high activity against T20-resistant strains [210]. Most of these lipopeptides are palmitic acid modified with existing CHR-peptides containing or lacking PBD. Lipopeptides have better activity, half-life and genetic barrier than their precursor peptides, but, as a consequence, they cost more. A large number of resistant strains against CHR-peptides have emerged, greatly limiting the use of most CHR-peptides. Whether resistance to lipopeptides will occur in the future is still the focus of our attention. 
Covalent binding of cholesterol to C34 obtained C34-chol (DS007). C34-chol has high affinity to lipid rafts of cell membranes and inhibits the formation of $6 \mathrm{HB}$ during viral infection. The activity of C34-chol to inhibit multiple HIV-1 isolates in vitro is about 25- to 100-fold that of C34 activity [211], indicating that linking cholesterol to HR-derived peptide inhibitors is an effective strategy for increasing antiviral activity. Furthermore, this strategy can also be applied to enhance the antiviral activity of fusion inhibitory peptides against enveloped viruses, such as influenza virus, suggesting that the role of cholesterol in the design of HIV-1 entry inhibitors deserves more attention. In contrast, palmitic acid used in lipids to enhance the interaction of peptides with cell membranes is more convenient and economical than cholesterol and sphingolipids [199]. In addition to enhancing the binding to lipids, palmitic acid can also bind to human serum albumin, which can reduce the rate of glomerular elimination [212] and prolong the half-life of the drug in vivo.

Lipid rafts are thought to be the hallmark of HIV-1 budding and entry into T cells and macrophages $[190,213,214]$, and many glycosylphosphatidylinositol (GPI)-anchored proteins are localized in lipid rafts. GPI-C34 (C34 anchored with GPI) has been shown to bind to lipid rafts via GPI anchors and broadly inhibit HIV-1 infection [215]. This again proves that the inclusion of substances capable of binding to lipid membranes in HIV inhibitors is an effective way to increase the activity of inhibitors.

\subsubsection{Peptides Targeting gp $41 \mathrm{CHR}$}

The focus on developing CHR-peptides arises from the early discovery of some NHR-derived peptides that interact with $\mathrm{CHR}$ to inhibit the formation of homologous $6 \mathrm{HB}$, but they have lower inhibitory activity and are unstable. Here is a summary of the amino acid sequences of NHR-peptides and their inhibition of cell-cell fusion activity (Figure 4).

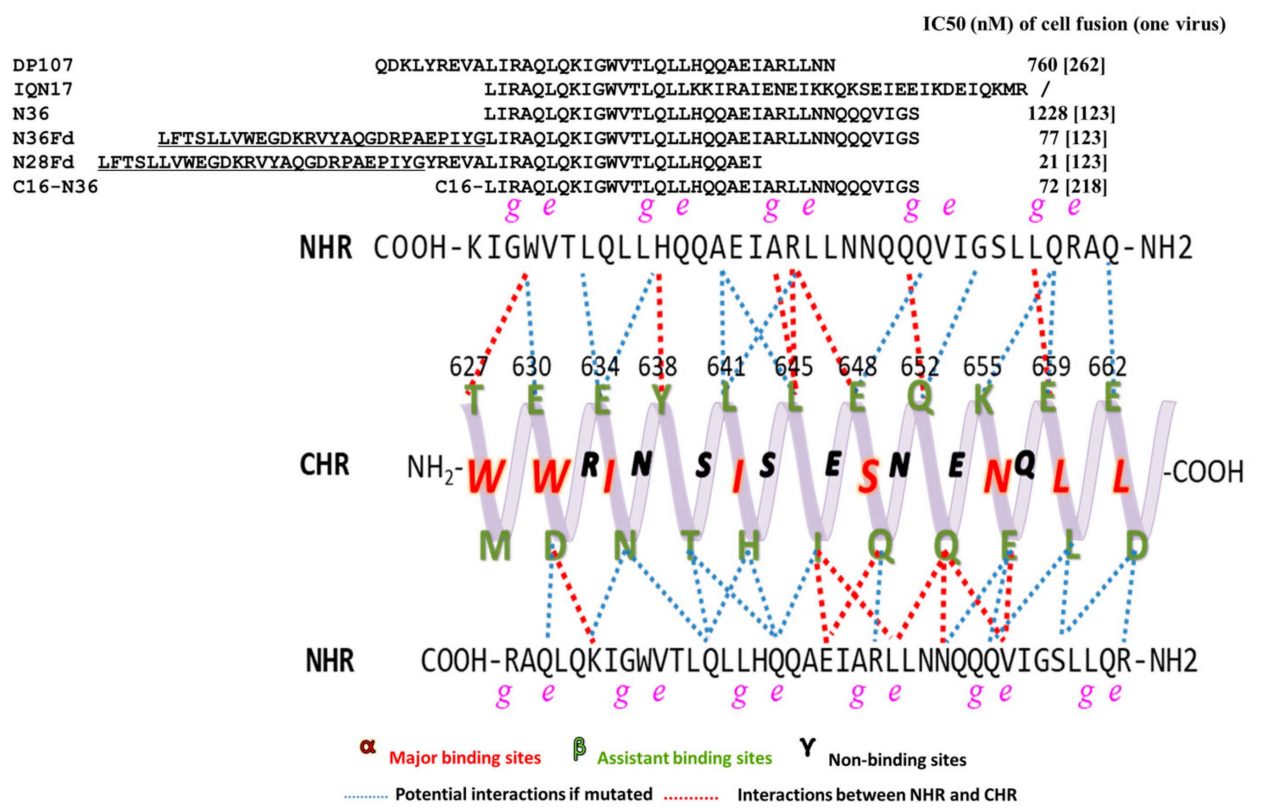

Figure 4. Tripartite model of gp41 C-terminal heptad repeats (CHR) with side view and N-terminal heptad repeats (NHR)-derived peptides. Above, the sequences of peptides targeting CHR. The sequences of Fd are underlined. Below, residues of CHR are divided into three groups: major binding sites $\alpha$, assistant binding sites $\beta$, and nonbinding sites $\gamma$. The interaction, or potential interaction, between $\mathrm{CHR}$ and NHR is shown in red or blue dashed lines. 
N36, an NHR-peptide with 36-amino acid residues derived from the HIV-1 gp41 NHR, can interact with a CHR-peptide derived from the gp41 CHR to form 6HB in vitro [216]. Theoretically, it should have inhibitory activity against HIV-1 infection since it can interact with the viral gp41 NHR to form heterologous $6 \mathrm{HB}$, thus blocking fusion between viral and cell membranes. However, N36 and other NHR-derived NHR-peptides have the tendency to aggregate in neutral buffer because of its strong hydrophobicity, thus exhibiting very low viral fusion inhibitory activity (about hundreds of folds lower than that of a CHR-peptide) [178]. The peptide N36 Mut(e,g) was designed by replacing the hydrophobic residues at the e, g positions of N36 with hydrophilic residues so that this NHR-peptide cannot interact with $\mathrm{CHR}$ to form $6 \mathrm{HB}$, while it remains soluble in physiological solutions or PBS. N36 ${ }^{\text {Mut }(e, g)}$ showed HIV-1 inhibitory activity at sub-micromolar level. This peptide may interact with the viral gp41 NHR to form non-functional heterologous NHR trimer, resulting in the inhibition of fusion between the viral and target cell membranes [217]. Shai and colleagues have shown that N27, a 27-residue NHR-peptide with no PBD, has no significant inhibitory activity in the cell-cell fusion; but it became very active $(\mathrm{IC} 50=10 \mathrm{nM})$ when palmitic acid (C16) was conjugated to its $\mathrm{N}$ terminus (C16-N27), but not C terminus (N27-C16). Interestingly, N27 Mut(e,g), which has the similar mutations as N36 $6^{\mathrm{Mut}(\mathrm{e}, \mathrm{g})}$, exhibited no cell fusion inhibitory activity either. C16 conjugated at its N-terminus, i.e., C16-N27 Mut(e,g), showed some inhibitory against HIV-1 Env-mediated cell-cell fusion, but it is about 63-fold lower than that of C16-N27 [202], suggesting that N27 mainly targets the CHR rather than the internal NHR coiled-coil. This group has also demonstrated that conjugation of $\mathrm{C} 16$ to either $\mathrm{N}$ - or C-terminus of $\mathrm{N} 36$ results in increase of membrane fusion inhibitory activity, while the inhibitory activity of N36 ${ }^{\mathrm{Mut}(\mathrm{e}, \mathrm{g})}-\mathrm{C} 16$ is about 17-fold stronger than that of C16-N36 ${ }^{\mathrm{Mut}(\mathrm{e}, \mathrm{g})}$ [202,218], suggesting a planar orientation of the peptide and the endogenous NHR region on the cell membrane. suggesting a planar orientation of the peptides as well as the endogenous NHR region on the cell membrane.

Efforts have focused on how to enhance NHR-peptide solubility and maintain its natural trimer structure. Kim added a highly trimerized model peptide, such as GCN4 sequence, IQ, IZ, and others, to N17 to form recombinant IQN17 and CC-IZN17. They were all highly soluble, formed trimer structure and increased anti-HIV activity from $\mu \mathrm{M}$ to low $\mathrm{nM}$ range [159].

Mutated NHR-peptides, however, are not quite stable compared to CHR-peptide; therefore, they cannot maintain their antiviral activity for very long. Nevertheless, the study of NHR-peptide fusion inhibitors is still attractive because these inhibitors have the advantage of targeting gp $41 \mathrm{CHR}$, which may avoid cross-drug resistance with currently used fusion inhibitor T20 and other CHR-peptide fusion inhibitors under development [161].

\section{Protein-Based HIV Entry Inhibitors Targeting both gp120 and gp41}

In vitro data show that inhibitors targeting gp120 and gp41 have potent antiviral activity. The discovery of some antibodies targeting both gp120 and gp41 indicates that the N-terminal FP of gp41 can be exposed in solution and that it is a new target. The residues involved in the gp41-gp120 interface in the gp120 core were also resolved [7]. Furthermore, recombinant proteins with multiple targets have improved antiviral activity and may be less susceptible to inducing resistant strains and thus may be an attractive research direction.

\subsection{Antibodies Targeting both gp120 and gp41}

8ANC195, a bNAb isolated from HIV-1 patients; it neutralizes 118 HIV-1 tier 2 isolates with an IC50 of 0.5-12.1 $\mu \mathrm{g} / \mathrm{mL}$ [19]. Its epitopes include Asn 234 and Asn 276 on gp120, the inner region of gp120, loop D and loop V5 and may be involved in Asn637 and its adjacent amino acids on gp41 [219]. Since the epitope spans gp120 and gp41 in the native Env trimer, it becomes the first bNAb derived from humans acting on two subunits of Env.

$35 \mathrm{O} 22$ is a bNAb produced primarily in natural infections and targets the conserved interface of gp120-gp41. It recognizes the glycosylation sites N88A, N230A, N241A and N625A on the HIV-1 JRCSF strain Env and has higher neutralizing activity than PGT121 and VRC01. After gp120-sCD4 complex 
causes a change in the conformation of gp41, studies have shown that $35 \mathrm{O} 22$ binds to the exposed epitope at the interface of gp120-gp41 to exert neutralizing activity. Therefore, it does not compete with other bNAbs that target gp120 to bind viral particles [220]. Many HIV-1-infected individuals have antibodies similar to $35 \mathrm{O} 22$, which opens up the possibility of making vaccines similar to this antibody. Furthermore, the construction of immunogens that are structurally similar to natural Env trimers may have an important role in inducing such antibodies.

The bNAb VRC34.01 was derived from HIV-1 chronically infected individuals, inhibiting the conformational changes of HIV-1 gp120 and gp41 and blocking viral entry. Like 35O22, the epitope of VRC34.01 contains N88 on gp120, but it also targets the N-terminus of gp41 FP. Its neutralization profile is limited with a neutralization rate of $49 \%$ for 208 different HIV-1 strains at IC50 below $50 \mu \mathrm{g} / \mathrm{mL}$. Mutations in gp120 N88 and FP cause severe resistance to VRC34.01 [221]. However, molecular dynamics indicate that the N-terminus of FP can be exposed to solution, which means that the discovery of this antibody suggests that FP is also an important antibody recognition epitope.

PGT151 is a bNAb isolated from elite controllers infected with HIV-1 [222]. It targets the gp120-gp41 interface and FP of gp41 $[3,223]$ and stabilizes the highly unstable Env trimer structure. Compared to 8ANC195, 35O22 and VRC34.01, PGT151 has a broader neutralization profile with a neutralization rate of $68 \%$ for $208 \mathrm{HIV}-1$ at IC50 $<50 \mu \mathrm{g} / \mathrm{mL}$ [221].

bNAb ACS202, which targets the interface of gp120-gp41, was isolated from an elite controller infected with HIV-1. It interacts with gp120 residues and glycans (especially N88) and with gp41 FP and FPPR [224]. It only neutralized $45 \%$ of the 75 different subtypes of HIV- 1 strains with a median IC50 value of $0.142 \mu \mathrm{g} / \mathrm{mL}$. Although the neutralizing activity and range are not prominent, the discovery of this antibody revealed that conserved FP is a target for bNAb.

mAbs 3BC315 and 3BC176 were isolated from the same patient with moderate broad-spectrum, neutralizing activity and similar epitopes [225]. 3BC315/3BC176 targets the interface of gp120-gp41, and its mechanism of neutralizing activity may one that destroys the function and integrity of Env trimer, causing the shedding of gp120 [226]. 3BC315 / 3BC176 is sensitive to antibody-resistant strains targeting gp120 CD4bs in the same patient; therefore, the combination can broaden its neutralization profile.

mAb CAP248-2B was recently isolated from HIV-1 patients and targeted to the gp120-gp41 contact surface. Its epitope contains the C-terminus of gp120 and partially overlaps with the epitopes of PGT151, VRC34, 35O22 and 3BC315 on gp41 [227]. However, the neutralization range of CAP248-2B is limited, and some strains of gp120 C-terminal mutation can escape its neutralization.

mAb M43 was obtained by screening phage antibody Fab library and gp 41 specific mAb library using the competitive antigen panning (CAP) methodology [228]. The conformational epitope recognized by M43 contains CD4bs on gp120 and N-trimer structure on gp41. However, the neutralization activity and neutralization range may limit its application.

\subsection{Proteins Targeting both gp120 and gp41}

2DLT is a bivalent chimeric protein constructed by fusing T1144 with the first two extracellular domains of CD4 (D1D2). Unlike most entry inhibitors, it triggers early exposure of gp41 prior to viral fusion and rapidly inactivates viral particles [229]. Binding of D1D2 to CD4bs on gp120 causes a conformational change in gp120 and the exposed gp41, which results in the formation of a prehairpin fusion intermediate (PFI). T1144 then binds to the exposed PFI and causes the cell-free virus to rapidly "inactivate". The EC50 of 2DLT inactivated different HIV-1 isolates ranging from 17.3 to $78.6 \mathrm{nM}$, making it more effective than T20 and T1144 (EC50 >500 nM). What's more, 2DLT can be produced in large quantities in E. coli and exhibit synergy with other antiviral drugs, rather than mediating HIV-1 infection like sCD4 $[229,230]$. This chimeric protein can serve as a dual barrier against HIV-1 infection. First, HIV-1 is "inactivated" and unable to infect target cells. Second, if the virus evades the first attack of 2DLT, T1144 in 2DLT can inhibit viral-cell fusion as a fusion inhibitor.

sCD4-FIT45 is a bispecific protein in which sCD4 is covalently linked to a 45 amino acid CHR-peptide T45 [231] targeting gp41 NHR. Similar to 2DLT, sCD4 in sCD4-FIT45 interacts with gp120 
to expose gp41 NHR, followed by T45 targeting NHR, inactivating cell-free virus [232]. Unlike sCD4, the bispecific protein sCD4-FIT45 does not cause HIV-1 Env-mediated CD4 ${ }^{-} \mathrm{CCR} 5^{+}$cell infection [233], probably owing to the important role of FIT45.

Griff37 consists of a GRFT (griffithsin) targeting gp120 and a peptide C37 (3 more amino acids at the N-terminus of C34) targeting gp41 NHR. It inhibits cell-cell fusion and HIV-1 infection at mid-nanomolar and mid-picomolar levels, respectively, and its inhibitory activity is more effective than that of GRFT or C37 or a combination of both [234]. This further demonstrates that GRFT activity can be increased by coupling drugs of different targets. In addition, since the resistant strain against GRFT has emerged [106], Griff37 has dual targeting and may increase the genetic barrier.

C37CD4M33C1F23 is a dual-targeted recombinant protein formed by covalent attachment of peptide C37 targeting gp41 NHR to CD4M33C1F23 (with Cys at position 1 and Phe at position 23) targeting gp120 [234]. The recombinant protein inhibited the activity of the CCR5-tropic fusion assay significantly higher than the individual components, although the difference was not significant in the inhibition of the CXCR4-tropic fusion assay. However, because of the simplicity of preparation of the recombinant protein, this strategy can be used as a reference to guide the synthesis of other recombinant proteins.

\section{Conclusions}

Since the first peptide-based HIV entry inhibitor, enfuvirtide, was approved for clinical use by the U.S. FDA in 2003, about nine series of protein- and peptide-based HIV entry inhibitors have been developed in pre-clinical and clinical studies (Table 1). Different from most of the current ARDs that must enter the host cells to inhibit HIV replication, these entry inhibitors block HIV entry into the host cells by targeting the site(s) on the viral surface proteins, including the CD4bs, CoRbs, variable loop region, and glycans on gp120, or FP, NHR, or CHR, 6HB, and MPER on gp41. Therefore, these big molecules (proteins or peptides) without cell-penetrating ability can act on the surface of cells to block the virus entry into the cell or transmission between the cells. They are expected to have no adverse effects on the functions of the intracellular proteins. High specificity, potency and safety are the advantages of the protein- and peptide-based HIV entry inhibitors, while high cost of production and lack of oral availability are their disadvantages, compared with the current ARDs. However, these may not be a concern if they are used to treat the patients at the early stage of highly pathogenic virus infection with high mortality, as a short-term (1-2 weeks) injection of a protein- or peptide-based virus entry inhibitor at high dosage is expected to save the patients' lives.

Currently, a number of protein-based HIV entry inhibitors, particularly the gp120- or gp41-specific neutralizing antibodies, with high specificity, efficacy and safety, as well as long half-life in vivo have been reported [14,138,235-237]. Some of them are already undergoing clinical trials [22,23,138,141]. Unlike the protein-based HIV entry inhibitors that must be stored and transported at low temperature, the peptide-based HIV entry inhibitors can be stored and transported at normal temperature. However, the peptide-based HIV entry inhibitors are generally susceptible to protease degradation, thus having shorter half-life in vivo [238-240]. Some studies have attempted to use E. coli expression systems or conjugation techniques to reduce the cost of inhibitors or enhance stability [192,211,241]. In addition, the emergence of drug-resistant strains is also an urgent problem to be solved. Therefore, optimization of the sequence and structure of the peptide-based HIV inhibitors for the purpose of prolonging their half-life, enhancing their anti-HIV potency, improving their druggability, and delaying the emergence of drug-resistant strains by combinational use of two or more HIV entry inhibitors with different targets are essential for their future development. 
Table 1. Protein-and peptide-based HIV entry inhibitors targeting gp120 or gp41.

\begin{tabular}{|c|c|c|c|c|c|c|c|}
\hline \multirow{2}{*}{ Inhibitor } & \multicolumn{2}{|c|}{$\mathrm{IC}_{50}$} & \multirow{2}{*}{$\begin{array}{l}\text { No. of } \\
\text { Isolates }\end{array}$} & \multirow{2}{*}{$\begin{array}{l}\text { Target } \\
\text { Cells }\end{array}$} & \multirow{2}{*}{$\begin{array}{c}\text { Animal } \\
\text { Trials }\end{array}$} & \multirow{2}{*}{$\begin{array}{l}\text { Clinical } \\
\text { Phase }\end{array}$} & \multirow{2}{*}{ Reference } \\
\hline & $\mu \mathrm{g} / \mathrm{mL}$ & nM & & & & & \\
\hline \multicolumn{8}{|c|}{ Inhibitors targeting gp120 CD4bs } \\
\hline \multicolumn{8}{|c|}{ Proteins } \\
\hline $\mathrm{D} 1 \mathrm{D} 2 / \mathrm{mD} 1.2$ & & $35 / 19^{a}$ & 13 & HOS & & & [57] \\
\hline PRO-542 & $7^{\text {a }}$ & & 28 & PBMC & mice & Terminated & {$[53,54]$} \\
\hline $6 \mathrm{Dm} 2 \mathrm{~m}$ & & $0.32^{\mathrm{a}}$ & 41 & TZM-bl & & & [58] \\
\hline VRC01 & $0.33^{b}$ & & 190 & TZM-bl & NHP, mice & I & {$[14,235,236]$} \\
\hline b12 & $1.79^{b}$ & & 190 & TZM-bl & NHP, mice & & {$[14,36,242]$} \\
\hline NIH45-46/45-46m2 & $0.41^{\mathrm{b}} / 0.028^{\mathrm{b}}$ & & $65 / 118$ & TZM-bl & mice & & {$[20,21,235]$} \\
\hline N6 & $0.038^{c}$ & & 181 & TZM-bl & NHP & I & {$[22,23]$} \\
\hline 3BNC117 & $0.11^{\mathrm{c}}$ & & 180 & TZM-bl & NHP, mice & II & {$[24,25,28,138]$} \\
\hline PGV04 & $0.19^{b}$ & & 178 & TZM-bl & & & [32] \\
\hline \multicolumn{8}{|c|}{ Peptides } \\
\hline CD4M33 & & $424.7^{\mathrm{a}}$ & 4 & PBMC & & & [65] \\
\hline M48U1 & & $0.71^{\mathrm{a}}$ & 4 & GHOST & NHP & & {$[68,70]$} \\
\hline \multicolumn{8}{|c|}{ Inhibitors targeting gp120 CoRbs } \\
\hline \multicolumn{8}{|c|}{ Proteins } \\
\hline $17 \mathrm{~b}$ & NA & & 7 & Cf2Th & & & [82] \\
\hline E51 & NA & & 7 & Cf2Th & & & [82] \\
\hline M36/M36.4 & & $17^{\mathrm{b}} / 7.3^{\mathrm{b}}$ & 13 & HOS & & & [78] \\
\hline \multicolumn{8}{|c|}{ Peptides } \\
\hline $\mathrm{pV} 2 \alpha$-Tys & & $<50000^{a}$ & 12 & $\begin{array}{l}\text { primary } \\
\text { human } \\
\text { CD4+ T } \\
\text { primary }\end{array}$ & & & [85] \\
\hline pCCR5-Tys & & $>50000^{\mathrm{a}}$ & 12 & $\begin{array}{l}\text { human } \\
\mathrm{CD} 4+\mathrm{T}\end{array}$ & & & [85] \\
\hline \multicolumn{8}{|c|}{ Inhibitors targeting gp120 variable loops or glycans } \\
\hline \multicolumn{8}{|c|}{ Proteins } \\
\hline F105 & & NA & & & NHP & I & [243] \\
\hline 2G12 & $2.43^{c}$ & & 162 & U87 & NHP/mice & II & {$[89,244-246]$} \\
\hline PG9/ PG16 & $0.2 / 0.15^{c}$ & & 177 & TZM-bl & NHP/mice & & {$[138,236,247]$} \\
\hline $\mathrm{CH} 03$ & $0.46^{c}$ & & 91 & TZM-bl & & & [95] \\
\hline $10-1074$ & $0.18^{\mathrm{d}}$ & & 306 & TZM-bl & NHP/mice & I & {$[21,100,247,248]$} \\
\hline PGT121 & $10.49^{c}$ & & 162 & U87 & $\mathrm{NHP} /$ mice & I & {$[23,96,249,250]$} \\
\hline PGT128 & $2.73^{c}$ & & 162 & U87 & $\mathrm{NHP} /$ mice & & {$[96,251,252]$} \\
\hline $\mathrm{CV}-\mathrm{N}$ & & $8.2^{\mathrm{a}}$ & 20 & TZM-bl & & & [253] \\
\hline GRFT & & $1.0^{\mathrm{a}}$ & 18 & TZM-bl & & & [253] \\
\hline \multicolumn{8}{|c|}{ Inhibitors targeting gp41 FP } \\
\hline & & & Peptic & & & & \\
\hline VIR-576 & & NA & & PBMC & & Terminated & [142] \\
\hline E1P47 & & $8200^{a}$ & 6 & TZM-bl & & & [154] \\
\hline & & Inh & ors targeti & gp41 NHR & & & \\
\hline & & & Prote & & & & \\
\hline D5 & & $554.4^{\mathrm{a}}$ & 5 & U87 & & & [109] \\
\hline HK20 & $25.2^{\mathrm{a}}$ & & 18 & HOS & & & [115] \\
\hline $8 \mathrm{~K} 8$ & & $253.6^{\mathrm{a}}$ & 11 & U87 & & & [116] \\
\hline C52L & & $21.5^{\mathrm{a}}$ & 8 & PBMC & $\mathrm{NHP} /$ mice & & {$[117,254,255]$} \\
\hline TLT35 & & $5.7^{\mathrm{a}}$ & 11 & $\begin{array}{l}\text { PBMC, } \\
\text { MT-2 }\end{array}$ & & & [118] \\
\hline HR212 & & 2.8 & 1 & GHOST & & & [256] \\
\hline & & & Peptic & & & & \\
\hline SJ-2176 & & $101^{\mathrm{a}}$ & 1 & MT-2 & & & {$[163,164]$} \\
\hline $\mathrm{T} 20$ & & $29.45^{a}$ & 25 & TZM-bl & NHP, mice & Approved & [165] \\
\hline $\mathrm{C} 34$ & & $12.5^{\mathrm{a}}$ & 10 & MT-2, M7 & & & [166] \\
\hline SFT & & $50^{a}$ & 6 & PBMC & NHP, mice & Terminated & {$[189,257,258]$} \\
\hline SC29EK & & $9.6^{\mathrm{a}}$ & 7 & $\mathrm{HeLa}$ & & & [185] \\
\hline $\mathrm{T} 1249$ & & $3.44^{\mathrm{a}}$ & 25 & TZM-bl & NHP & Terminated & {$[259,260]$} \\
\hline T1144 & & $13.9^{a}$ & 11 & $\begin{array}{l}\text { PBMC, } \\
\text { MT-2 }\end{array}$ & & & {$[118,184]$} \\
\hline FB006M & & $2.7^{\mathrm{a}}$ & 8 & PBMC & NHP, mice & Approved & [192] \\
\hline CP32M & & $65^{a}$ & 10 & PBMC & & & [193] \\
\hline HP23 & & $4.7^{\mathrm{a}}$ & 29 & TZM-bl & & & [195] \\
\hline AP3 & & $19^{a}$ & 8 & MT-2, M7 & & & [197] \\
\hline
\end{tabular}


Table 1. Cont.

\begin{tabular}{|c|c|c|c|c|c|c|c|}
\hline \multirow{2}{*}{ Inhibitor } & \multicolumn{2}{|c|}{$\mathrm{IC}_{50}$} & \multirow{2}{*}{$\begin{array}{l}\text { No. of } \\
\text { Isolates }\end{array}$} & \multirow{2}{*}{$\begin{array}{l}\text { Target } \\
\text { Cells }\end{array}$} & \multirow{2}{*}{$\begin{array}{c}\text { Animal } \\
\text { Trials }\end{array}$} & \multirow{2}{*}{$\begin{array}{l}\text { Clinical } \\
\text { Phase }\end{array}$} & \multirow{2}{*}{ Reference } \\
\hline & $\mu \mathrm{g} / \mathrm{mL}$ & $\mathrm{nM}$ & & & & & \\
\hline HP23-E6-IDL & & $0.75^{\mathrm{a}}$ & 12 & MT-2, M7 & & & [208] \\
\hline CHR2 & & $2.4^{\mathrm{a}}$ & 22 & MT-2, M7 & & & {$[168]$} \\
\hline YIK-C16 & & 0.09 a & 18 & MT-2, M7 & & & [209] \\
\hline MT-WQ-IDL & & $2.7^{\mathrm{a}}$ & 24 & MT-2, M7 & & & [172] \\
\hline LP-11 & & $0.83^{a}$ & 25 & TZM-bl & & & [206] \\
\hline LP40 & & 4.29 a & 25 & TZM-bl & & & [206] \\
\hline LP46 & & $0.08^{\mathrm{a}}$ & 25 & TZM-bl & & & [210] \\
\hline LP52 & & $0.017^{\mathrm{a}}$ & 35 & TZM-bl & & & [210] \\
\hline C34-chol & & $15.5^{\mathrm{a}}$ & 6 & HeLa & mice & & [211] \\
\hline \multicolumn{8}{|c|}{ Inhibitors targeting gp $41 \mathrm{CHR}$} \\
\hline \multicolumn{8}{|c|}{ Proteins } \\
\hline FC-1 & $9.7^{\mathrm{a}}$ & & 10 & $\begin{array}{l}\text { SupT1, } \\
\text { PBMC }\end{array}$ & & & [120] \\
\hline $\mathrm{N}_{\mathrm{CCG}}$-gp41 & & NA & & & & & [122] \\
\hline ccN28Fd & & $27.7^{\mathrm{a}}$ & 8 & PBMC & & & [124] \\
\hline HR121 & & 16.2 & 1 & GHOST & & & [256] \\
\hline 5-Helix & & $3.6^{\mathrm{a}}$ & 4 & HOS & & & [261] \\
\hline \multicolumn{8}{|c|}{ Peptides } \\
\hline DP107 & & 320 & 1 & TZM-bl & & & [262] \\
\hline IZN17 & & 22 & 1 & HOS & & & [159] \\
\hline N36 & & $509.8^{\text {a }}$ & 8 & MT-2 & & & [263] \\
\hline \multicolumn{8}{|c|}{ Inhibitors targeting gp $416 \mathrm{HB}$} \\
\hline \multicolumn{8}{|c|}{ Proteins } \\
\hline P20-A & & $5700^{\mathrm{a}}$ & 14 & $\begin{array}{l}\text { MT-2, } \\
\text { TZM-bl }\end{array}$ & & & [131] \\
\hline C60 & & $12200^{a}$ & 2 & $\begin{array}{l}\text { MT-2, } \\
\text { TZM-bl }\end{array}$ & & & [133] \\
\hline \multicolumn{8}{|c|}{ Inhibitors targeting gp 41 MPER } \\
\hline \multicolumn{8}{|c|}{ Proteins } \\
\hline $2 \mathrm{~F} 5$ & $14.6^{\mathrm{c}}$ & & 177 & TZM-bl & $\mathrm{NHP} /$ mice & II & {$[138,237]$} \\
\hline $4 \mathrm{E} 10$ & $1.93^{c}$ & & 181 & TZM-bl & NHP & II & [138] \\
\hline $10 \mathrm{E} 8$ & $0.35^{\mathrm{c}}$ & & 180 & TZM-bl & NHP & I & {$[138,236]$} \\
\hline 10E8v2.0/iMab & $0.002^{c}$ & & 118 & TZM-bl & mice & & [140] \\
\hline 10E8.4/iMab & $0.0008^{c}$ & & 118 & TZM-bl & mice & I & [141] \\
\hline \multicolumn{8}{|c|}{ Inhibitors targeting both gp120 and gp41 } \\
\hline 8ANC195 & NA & & & & mice & & [264] \\
\hline $35 \mathrm{O} 22$ & $0.056^{\mathrm{b}}$ & & 181 & TZM-bl & & & [220] \\
\hline VRC34.01 & $0.35^{\mathrm{b}}$ & & 16 & TZM-bl & & & [221] \\
\hline PGT151 & $0.008^{c}$ & & 77 & TZM-bl & & & [222] \\
\hline ACS202 & $0.14^{\mathrm{c}}$ & & 75 & TZM-bl & & & [224] \\
\hline 3ВС176 & $1.69^{\mathrm{c}}$ & & 25 & TZM-bl & & & [226] \\
\hline Griff37 & & $0.08^{\mathrm{a}}$ & 4 & PBMC & & & [234] \\
\hline $\mathrm{C} 37 \mathrm{CD} 4 \mathrm{M} 33_{\mathrm{C} 1 \mathrm{~F} 23}$ & & $2.29^{\mathrm{a}}$ & 2 & $\begin{array}{l}\text { TZM-bl } \\
\text { MT-2, }\end{array}$ & & & [234] \\
\hline 2DLT & & $14^{\text {a }}$ & 5 & $\begin{array}{l}\text { TZM-bl, } \\
\text { PBMC }\end{array}$ & & & [229] \\
\hline sCD4-FIT45 & $0.12^{c}$ & & 16 & TZM-bl & & & [233] \\
\hline
\end{tabular}

a Arithmetic mean; ${ }^{\mathrm{b}}$ Geometric mean; ${ }^{\mathrm{c}}$ median $\mathrm{IC}_{50} ;{ }^{\mathrm{d}}$ Geometric mean $\mathrm{IC}_{80}$; NA, not applicable; Non-human primate (NHP).

Author Contributions: All authors contributed to the final manuscript.

Funding: This work was supported by grants from the National Natural Science Foundation of China (81630090 to S.J.; 81672019,81822045 and 81661128041 to L.L; 81701998 to QW; 81703571 to WX).

Acknowledgments: We would like to thank Haiyan Huang (Yantai Yuhuangding Hospital, Qingdao University, Yantai, Shandong, China) for her contribution to collecting content and drawing figures. We thank Guangzhou SageneBiotech Co., LTD for the assistance in preparing the figures with high quality.

Conflicts of Interest: The authors declare no competing financial interests.

\section{References}

1. Avila-Rios, S.; Garcia-Morales, C.; Matias-Florentino, M.; Romero-Mora, K.A.; Tapia-Trejo, D.; Quiroz-Morales, V.S.; Reyes-Gopar, H.; Ji, H.; Sandstrom, P.; Casillas-Rodriguez, J.; et al. Pretreatment HIV-drug resistance in Mexico and its impact on the effectiveness of first-line antiretroviral therapy: A nationally representative 2015 WHO survey. Lancet HIV 2016, 3, e579-e591. [CrossRef] 
2. Lu, L.; Tong, P.; Yu, X.; Pan, C.; Zou, P.; Chen, Y.H.; Jiang, S. HIV-1 variants with a single-point mutation in the gp41 pocket region exhibiting different susceptibility to HIV fusion inhibitors with pocket- or membrane-binding domain. Biochim. Biophys. Acta 2012, 1818, 2950-2957. [CrossRef] [PubMed]

3. Lee, J.H.; Ozorowski, G.; Ward, A.B. Cryo-EM structure of a native, fully glycosylated, cleaved HIV-1 envelope trimer. Science 2016, 351, 1043-1048. [CrossRef] [PubMed]

4. Julien, J.P.; Cupo, A.; Sok, D.; Stanfield, R.L.; Lyumkis, D.; Deller, M.C.; Klasse, P.J.; Burton, D.R.; Sanders, R.W.; Moore, J.P.; et al. Crystal structure of a soluble cleaved HIV-1 envelope trimer. Science 2013, 342, 1477-1483. [CrossRef] [PubMed]

5. Wang, H.; Cohen, A.A.; Galimidi, R.P.; Gristick, H.B.; Jensen, G.J.; Bjorkman, P.J. Cryo-EM structure of a CD4-bound open HIV-1 envelope trimer reveals structural rearrangements of the gp120 V1V2 loop. Proc. Natl. Acad. Sci. USA 2016, 113, e7151-e7158. [CrossRef] [PubMed]

6. Shaik, M.M.; Peng, H.; Lu, J.; Rits-Volloch, S.; Xu, C.; Liao, M.; Chen, B. Structural basis of coreceptor recognition by HIV-1 envelope spike. Nature 2019, 565, 318-323. [CrossRef] [PubMed]

7. Pancera, M.; Majeed, S.; Ban, Y.E.; Chen, L.; Huang, C.C.; Kong, L.; Kwon, Y.D.; Stuckey, J.; Zhou, T.; Robinson, J.E.; et al. Structure of HIV-1 gp120 with gp41-interactive region reveals layered envelope architecture and basis of conformational mobility. Proc. Natl. Acad. Sci. USA 2010, 107, 1166-1171. [CrossRef]

8. Finzi, A.; Xiang, S.H.; Pacheco, B.; Wang, L.; Haight, J.; Kassa, A.; Danek, B.; Pancera, M.; Kwong, P.D.; Sodroski, J. Topological layers in the HIV-1 gp120 inner domain regulate gp41 interaction and CD4-triggered conformational transitions. Mol. Cell 2010, 37, 656-667. [CrossRef]

9. Chan, D.C.; Fass, D.; Berger, J.M.; Kim, P.S. Core structure of gp41 from the HIV envelope glycoprotein. Cell 1997, 89, 263-273. [CrossRef]

10. Lu, L.; Zhu, Y.; Huang, J.; Chen, X.; Yang, H.; Jiang, S.; Chen, Y.H. Surface exposure of the HIV-1 env cytoplasmic tail LLP2 domain during the membrane fusion process: Interaction with gp41 fusion core. J. Biol. Chem. 2008, 283, 16723-16731. [CrossRef]

11. Starcich, B.R.; Hahn, B.H.; Shaw, G.M.; McNeely, P.D.; Modrow, S.; Wolf, H.; Parks, E.S.; Parks, W.P.; Josephs, S.F.; Gallo, R.C.; et al. Identification and characterization of conserved and variable regions in the envelope gene of HTLV-III/LAV, the retrovirus of AIDS. Cell 1986, 45, 637-648. [CrossRef]

12. Huang, C.C.; Tang, M.; Zhang, M.Y.; Majeed, S.; Montabana, E.; Stanfield, R.L.; Dimitrov, D.S.; Korber, B.; Sodroski, J.; Wilson, I.A.; et al. Structure of a V3-containing HIV-1 gp120 core. Science 2005, 310, 1025-1028. [CrossRef] [PubMed]

13. Zhou, T.; Georgiev, I.; Wu, X.; Yang, Z.Y.; Dai, K.; Finzi, A.; Kwon, Y.D.; Scheid, J.F.; Shi, W.; Xu, L.; et al. Structural basis for broad and potent neutralization of HIV-1 by antibody VRC01. Science 2010, 329, 811-817. [CrossRef] [PubMed]

14. Wu, X.; Yang, Z.Y.; Li, Y.; Hogerkorp, C.M.; Schief, W.R.; Seaman, M.S.; Zhou, T.; Schmidt, S.D.; $\mathrm{Wu}, \mathrm{L} . ; \mathrm{Xu}$, L.; et al. Rational design of envelope identifies broadly neutralizing human monoclonal antibodies to HIV-1. Science 2010, 329, 856-861. [CrossRef] [PubMed]

15. Abela, I.A.; Berlinger, L.; Schanz, M.; Reynell, L.; Gunthard, H.F.; Rusert, P.; Trkola, A. Cell-cell transmission enables HIV-1 to evade inhibition by potent CD4bs directed antibodies. PLoS Pathog. 2012, 8, e1002634. [CrossRef] [PubMed]

16. Tachibana, S.; Sasaki, M.; Tanaka, T.; Inoue, M.; Ophinni, Y.; Kotaki, T.; Kameoka, M. A 2-4-Amino acid deletion in the V5 region of HIV-1 env gp120 confers viral resistance to the broadly neutralizing human monoclonal antibody, VRC01. AIDS Res. Hum. Retrovir. 2017, 33, 1248-1257. [CrossRef] [PubMed]

17. Lynch, R.M.; Boritz, E.; Coates, E.E.; DeZure, A.; Madden, P.; Costner, P.; Enama, M.E.; Plummer, S.; Holman, L.; Hendel, C.S.; et al. Virologic effects of broadly neutralizing antibody VRC01 administration during chronic HIV-1 infection. Sci. Transl. Med. 2015, 7, 319ra206. [CrossRef] [PubMed]

18. Guo, D.; Shi, X.; Arledge, K.C.; Song, D.; Jiang, L.; Fu, L.; Gong, X.; Zhang, S.; Wang, X.; Zhang, L. A single residue within the V5 region of HIV-1 envelope facilitates viral escape from the broadly neutralizing monoclonal antibody VRC01. J. Biol. Chem. 2012, 287, 43170-43179. [CrossRef] [PubMed]

19. Scheid, J.F.; Mouquet, H.; Ueberheide, B.; Diskin, R.; Klein, F.; Oliveira, T.Y.; Pietzsch, J.; Fenyo, D.; Abadir, A.; Velinzon, K.; et al. Sequence and structural convergence of broad and potent HIV antibodies that mimic CD4 binding. Science 2011, 333, 1633-1637. [CrossRef] 
20. Diskin, R.; Scheid, J.F.; Marcovecchio, P.M.; West, A.P., Jr.; Klein, F.; Gao, H.; Gnanapragasam, P.N.; Abadir, A.; Seaman, M.S.; Nussenzweig, M.C.; et al. Increasing the potency and breadth of an HIV antibody by using structure-based rational design. Science 2011, 334, 1289-1293. [CrossRef]

21. Diskin, R.; Klein, F.; Horwitz, J.A.; Halper-Stromberg, A.; Sather, D.N.; Marcovecchio, P.M.; Lee, T.; West, A.P., Jr.; Gao, H.; Seaman, M.S.; et al. Restricting HIV-1 pathways for escape using rationally designed anti-HIV-1 antibodies. J. Exp. Med. 2013, 210, 1235-1249. [CrossRef] [PubMed]

22. Huang, J.; Kang, B.H.; Ishida, E.; Zhou, T.; Griesman, T.; Sheng, Z.; Wu, F.; Doria-Rose, N.A.; Zhang, B.; McKee, K.; et al. Identification of a CD4-binding-site antibody to HIV that evolved near-pan neutralization breadth. Immunity 2016, 45, 1108-1121. [CrossRef] [PubMed]

23. Julg, B.; Pegu, A.; Abbink, P.; Liu, J.; Brinkman, A.; Molloy, K.; Mojta, S.; Chandrashekar, A.; Callow, K.; Wang, K.; et al. Virological control by the CD4-binding site antibody N6 in simian-human immunodeficiency virus-infected rhesus monkeys. J. Virol. 2017, 91, e00498-17. [CrossRef] [PubMed]

24. Barouch, D.H.; Whitney, J.B.; Moldt, B.; Klein, F.; Oliveira, T.Y.; Liu, J.; Stephenson, K.E.; Chang, H.W.; Shekhar, K.; Gupta, S.; et al. Therapeutic efficacy of potent neutralizing HIV-1-specific monoclonal antibodies in SHIV-infected rhesus monkeys. Nature 2013, 503, 224-228. [CrossRef] [PubMed]

25. Shingai, M.; Nishimura, Y.; Klein, F.; Mouquet, H.; Donau, O.K.; Plishka, R.; Buckler-White, A.; Seaman, M.; Piatak, M., Jr.; Lifson, J.D.; et al. Antibody-mediated immunotherapy of macaques chronically infected with SHIV suppresses viraemia. Nature 2013, 503, 277-280. [CrossRef] [PubMed]

26. Bournazos, S.; Gazumyan, A.; Seaman, M.S.; Nussenzweig, M.C.; Ravetch, J.V. Bispecific anti-HIV-1 antibodies with enhanced breadth and potency. Cell 2016, 165, 1609-1620. [CrossRef] [PubMed]

27. Caskey, M.; Klein, F.; Lorenzi, J.C.; Seaman, M.S.; West, A.P., Jr.; Buckley, N.; Kremer, G.; Nogueira, L.; Braunschweig, M.; Scheid, J.F.; et al. Viraemia suppressed in HIV-1-infected humans by broadly neutralizing antibody 3BNC117. Nature 2015, 522, 487-491. [CrossRef] [PubMed]

28. Lu, C.L.; Murakowski, D.K.; Bournazos, S.; Schoofs, T.; Sarkar, D.; Halper-Stromberg, A.; Horwitz, J.A.; Nogueira, L.; Golijanin, J.; Gazumyan, A.; et al. Enhanced clearance of HIV-1-infected cells by broadly neutralizing antibodies against HIV-1 in vivo. Science 2016, 352, 1001-1004. [CrossRef]

29. Scheid, J.F.; Horwitz, J.A.; Bar-On, Y.; Kreider, E.F.; Lu, C.L.; Lorenzi, J.C.; Feldmann, A.; Braunschweig, M.; Nogueira, L.; Oliveira, T.; et al. HIV-1 antibody 3BNC117 suppresses viral rebound in humans during treatment interruption. Nature 2016, 535, 556-560. [CrossRef]

30. Schoofs, T.; Klein, F.; Braunschweig, M.; Kreider, E.F.; Feldmann, A.; Nogueira, L.; Oliveira, T.; Lorenzi, J.C.; Parrish, E.H.; Learn, G.H.; et al. HIV-1 therapy with monoclonal antibody 3BNC117 elicits host immune responses against HIV-1. Science 2016, 352, 997-1001. [CrossRef]

31. Liu, Z.J.; Bai, J.; Liu, F.L.; Zhang, X.Y.; Wang, J.Z. Focus on the therapeutic efficacy of 3 BNC117 against HIV-1: In vitro studies, in vivo studies, clinical trials and challenges. Int. Immunopharmacol. 2017, 52, 44-50. [CrossRef] [PubMed]

32. Wu, X.; Zhou, T.; Zhu, J.; Zhang, B.; Georgiev, I.; Wang, C.; Chen, X.; Longo, N.S.; Louder, M.; McKee, K.; et al. Focused evolution of HIV-1 neutralizing antibodies revealed by structures and deep sequencing. Science 2011, 333, 1593-1602. [CrossRef] [PubMed]

33. Falkowska, E.; Ramos, A.; Feng, Y.; Zhou, T.; Moquin, S.; Walker, L.M.; Wu, X.; Seaman, M.S.; Wrin, T.; Kwong, P.D.; et al. PGV04, an HIV-1 gp120 CD4 binding site antibody, is broad and potent in neutralization but does not induce conformational changes characteristic of CD4. J. Virol. 2012, 86, 4394-4403. [CrossRef] [PubMed]

34. Posner, M.R.; Cavacini, L.A.; Emes, C.L.; Power, J.; Byrn, R. Neutralization of HIV-1 by F105, a human monoclonal antibody to the CD4 binding site of gp120. J. Acquir. Immune Defic. Syndr. 1993, 6, 7-14. [PubMed]

35. Chen, L.; Kwon, Y.D.; Zhou, T.; Wu, X.; O’Dell, S.; Cavacini, L.; Hessell, A.J.; Pancera, M.; Tang, M.; Xu, L.; et al. Structural basis of immune evasion at the site of CD4 attachment on HIV-1 gp120. Science 2009, 326, 1123-1127. [CrossRef] [PubMed]

36. Parren, P.W.; Ditzel, H.J.; Gulizia, R.J.; Binley, J.M.; Barbas, C.F., 3rd; Burton, D.R.; Mosier, D.E. Protection against HIV-1 infection in hu-PBL-SCID mice by passive immunization with a neutralizing human monoclonal antibody against the gp120 CD4-binding site. AIDS 1995, 9, F1-F6. [CrossRef] [PubMed] 
37. Kessler, J.A., 2nd; McKenna, P.M.; Emini, E.A.; Chan, C.P.; Patel, M.D.; Gupta, S.K.; Mark, G.E., 3rd; Barbas, C.F., 3rd; Burton, D.R.; Conley, A.J. Recombinant human monoclonal antibody IgG1b12 neutralizes diverse human immunodeficiency virus type 1 primary isolates. AIDS Res. Hum. Retrovir. 1997, 13, 575-582. [CrossRef]

38. McInerney, T.L.; McLain, L.; Armstrong, S.J.; Dimmock, N.J. A human IgG1 (b12) specific for the CD4 binding site of HIV-1 neutralizes by inhibiting the virus fusion entry process, but b12 Fab neutralizes by inhibiting a postfusion event. Virology 1997, 233, 313-326. [CrossRef]

39. Zhou, T.; Xu, L.; Dey, B.; Hessell, A.J.; Van Ryk, D.; Xiang, S.H.; Yang, X.; Zhang, M.Y.; Zwick, M.B.; Arthos, J.; et al. Structural definition of a conserved neutralization epitope on HIV-1 gp120. Nature 2007, 445, 732-737. [CrossRef]

40. Liu, J.; Bartesaghi, A.; Borgnia, M.J.; Sapiro, G.; Subramaniam, S. Molecular architecture of native HIV-1 gp120 trimers. Nature 2008, 455, 109-113. [CrossRef]

41. Ozorowski, G.; Pallesen, J.; de Val, N.; Lyumkis, D.; Cottrell, C.A.; Torres, J.L.; Copps, J.; Stanfield, R.L.; Cupo, A.; Pugach, P.; et al. Open and closed structures reveal allostery and pliability in the HIV-1 envelope spike. Nature 2017, 547, 360-363. [CrossRef] [PubMed]

42. Sattentau, Q.J.; Moore, J.P. The role of CD4 in HIV binding and entry. Philos. Trans. R. Soc. Lond. B Biol. Sci. 1993, 342, 59-66. [PubMed]

43. Traunecker, A.; Luke, W.; Karjalainen, K. Soluble CD4 molecules neutralize human immunodeficiency virus type 1. Nature 1988, 331, 84-86. [CrossRef] [PubMed]

44. Daar, E.S.; Li, X.L.; Moudgil, T.; Ho, D.D. High concentrations of recombinant soluble CD4 are required to neutralize primary human immunodeficiency virus type 1 isolates. Proc. Natl. Acad. Sci. USA 1990, 87, 6574-6578. [CrossRef] [PubMed]

45. Moore, J.P.; McKeating, J.A.; Huang, Y.X.; Ashkenazi, A.; Ho, D.D. Virions of primary human immunodeficiency virus type 1 isolates resistant to soluble CD4 (sCD4) neutralization differ in sCD4 binding and glycoprotein gp120 retention from sCD4-sensitive isolates. J. Virol. 1992, 66, 235-243. [PubMed]

46. Schooley, R.T.; Merigan, T.C.; Gaut, P.; Hirsch, M.S.; Holodniy, M.; Flynn, T.; Liu, S.; Byington, R.E.; Henochowicz, S.; Gubish, E.; et al. Recombinant soluble CD4 therapy in patients with the acquired immunodeficiency syndrome (AIDS) and AIDS-related complex. A phase I-II escalating dosage trial. Ann. Int. Med. 1990, 112, 247-253. [CrossRef] [PubMed]

47. Haim, H.; Si, Z.; Madani, N.; Wang, L.; Courter, J.R.; Princiotto, A.; Kassa, A.; DeGrace, M.; McGee-Estrada, K.; Mefford, M. Soluble CD4 and CD4-mimetic compounds inhibit HIV-1 infection by induction of a short-lived activated state. PLoS Pathog. 2009, 5, e1000360. [CrossRef] [PubMed]

48. Orloff, S.L.; Kennedy, M.S.; Belperron, A.A.; Maddon, P.J.; McDougal, J.S. Two mechanisms of soluble CD4 (sCD4)-mediated inhibition of human immunodeficiency virus type 1 (HIV-1) infectivity and their relation to primary HIV-1 isolates with reduced sensitivity to SCD4. J. Virol. 1993, 67, 1461-1471.

49. Allan, J.S. Receptor-mediated activation of immunodeficiency viruses in viral fusion. Science 1991, 252, 1322-1323. [CrossRef]

50. Schutten, M.; Andeweg, A.C.; Bosch, M.L.; Osterhaus, A.D. Enhancement of infectivity of a non-syncytium inducing HIV-1 by sCD4 and by human antibodies that neutralize syncytium inducing HIV-1. Scand. J. Immunol. 1995, 41, 18-22. [CrossRef]

51. Jacobson, J.M.; Lowy, I.; Fletcher, C.V.; O’Neill, T.J.; Tran, D.N.; Ketas, T.J.; Trkola, A.; Klotman, M.E.; Maddon, P.J.; Olson, W.C.; et al. Single-dose safety, pharmacology, and antiviral activity of the human immunodeficiency virus (HIV) type 1 entry inhibitor PRO 542 in HIV-infected adults. J. Infect Dis. 2000, 182, 326-329. [CrossRef] [PubMed]

52. Allaway, G.P.; Davis-Bruno, K.L.; Beaudry, G.A.; Garcia, E.B.; Wong, E.L.; Ryder, A.M.; Hasel, K.W.; Gauduin, M.C.; Koup, R.A.; McDougal, J.S.; et al. Expression and characterization of CD4-IgG2, a novel heterotetramer that neutralizes primary HIV type 1 isolates. AIDS Res. Hum. Retrovir. 1995, 11, 533-539. [CrossRef] [PubMed]

53. Gauduin, M.C.; Allaway, G.P.; Olson, W.C.; Weir, R.; Maddon, P.J.; Koup, R.A. CD4-immunoglobulin G2 protects Hu-PBL-SCID mice against challenge by primary human immunodeficiency virus type 1 isolates. J. Virol. 1998, 72, 3475-3478. [PubMed] 
54. Trkola, A.; Pomales, A.B.; Yuan, H.; Korber, B.; Maddon, P.J.; Allaway, G.P.; Katinger, H.; Barbas, C.F., 3rd; Burton, D.R.; Ho, D.D.; et al. Cross-clade neutralization of primary isolates of human immunodeficiency virus type 1 by human monoclonal antibodies and tetrameric CD4-IgG. J. Virol. 1995, 69, 6609-6617. [PubMed]

55. Jacobson, J.M.; Israel, R.J.; Lowy, I.; Ostrow, N.A.; Vassilatos, L.S.; Barish, M.; Tran, D.N.; Sullivan, B.M.; Ketas, T.J.; O'Neill, T.J. Treatment of advanced human immunodeficiency virus type 1 disease with the viral entry inhibitor PRO 542. Antimicrob. Agents Chemother. 2004, 48, 423-429. [CrossRef]

56. Sharma, D.; Balamurali, M.M.; Chakraborty, K.; Kumaran, S.; Jeganathan, S.; Rashid, U.; Ingallinella, P.; Varadarajan, R. Protein minimization of the gp120 binding region of human CD4. Biochemistry 2005, 44, 16192-16202. [CrossRef] [PubMed]

57. Chen, W.; Feng, Y.; Gong, R.; Zhu, Z.; Wang, Y.; Zhao, Q.; Dimitrov, D.S. Engineered single human CD4 domains as potent HIV-1 inhibitors and components of vaccine immunogens. J. Virol. 2011, 85, 9395-9405. [CrossRef]

58. Chen, W.; Feng, Y.; Prabakaran, P.; Ying, T.; Wang, Y.; Sun, J.; Macedo, C.D.; Zhu, Z.; He, Y.; Polonis, V.R.; et al. Exceptionally potent and broadly cross-reactive, bispecific multivalent HIV-1 inhibitors based on single human CD4 and antibody domains. J. Virol. 2014, 88, 1125-1139. [CrossRef]

59. Chen, W.; Bardhi, A.; Feng, Y.; Wang, Y.; Qi, Q.; Li, W.; Zhu, Z.; Dyba, M.A.; Ying, T.; Jiang, S. Improving the $\mathrm{CH} 1-\mathrm{CK}$ heterodimerization and pharmacokinetics of $4 \mathrm{Dm} 2 \mathrm{~m}$, a novel potent CD4-antibody fusion protein against HIV-1. MAbs 2016, 8, 761-774. [CrossRef]

60. Qi, Q.; Wang, Q.; Chen, W.; Yu, F.; Du, L.; Dimitrov, D.S.; Lu, L.; Jiang, S. Anti-HIV antibody and drug combinations exhibit synergistic activity against drug-resistant HIV-1 strains. J. Infect. 2017, 75, 68-71. [CrossRef]

61. Vita, C.; Drakopoulou, E.; Vizzavona, J.; Rochette, S.; Martin, L.; Menez, A.; Roumestand, C.; Yang, Y.S.; Ylisastigui, L.; Benjouad, A.; et al. Rational engineering of a miniprotein that reproduces the core of the CD4 site interacting with HIV-1 envelope glycoprotein. Proc. Natl. Acad. Sci. USA 1999, 96, 13091-13096. [CrossRef] [PubMed]

62. Li, H.; Guan, Y.; Szczepanska, A.; Moreno-Vargas, A.J.; Carmona, A.T.; Robina, I.; Lewis, G.K.; Wang, L.X. Synthesis and anti-HIV activity of trivalent CD4-mimetic miniproteins. Bioorg. Med. Chem. 2007, 15, 4220-4228. [CrossRef] [PubMed]

63. Li, H.; Song, H.; Heredia, A.; Le, N.; Redfield, R.; Lewis, G.K.; Wang, L.X. Synthetic bivalent CD4-mimetic miniproteins show enhanced anti-HIV activity over the monovalent miniprotein. Bioconjug. Chem. 2004, 15, 783-789. [CrossRef] [PubMed]

64. Ibrahim, S.; Bobb, K.; Harris, I.; Robinson, J.; DeVico, A.; Fouts, T.R. Antigenic comparison of HIV envelope complexes containing either sCD4, human anti-envelope monoclonal antibody A32, or CD4 mimic protein CD4M9. Retrovirology 2005, 2, S69. [CrossRef]

65. Martin, L.; Stricher, F.; Misse, D.; Sironi, F.; Pugniere, M.; Barthe, P.; Prado-Gotor, R.; Freulon, I.; Magne, X.; Roumestand, C.; et al. Rational design of a CD4 mimic that inhibits HIV-1 entry and exposes cryptic neutralization epitopes. Nat. Biotechnol. 2003, 21, 71-76. [CrossRef] [PubMed]

66. Stricher, F.; Huang, C.C.; Descours, A.; Duquesnoy, S.; Combes, O.; Decker, J.M.; Kwon, Y.D.; Lusso, P.; Shaw, G.M.; Vita, C.; et al. Combinatorial optimization of a CD4-mimetic miniprotein and cocrystal structures with HIV-1 gp120 envelope glycoprotein. J. Mol. Biol. 2008, 382, 510-524. [CrossRef]

67. Morellato-Castillo, L.; Acharya, P.; Combes, O.; Michiels, J.; Descours, A.; Ramos, O.H.; Yang, Y.; Vanham, G.; Arien, K.K.; Kwong, P.D.; et al. Interfacial cavity filling to optimize CD4-mimetic miniprotein interactions with HIV-1 surface glycoprotein. J. Med. Chem. 2013, 56, 5033-5047. [CrossRef]

68. Van Herrewege, Y.; Morellato, L.; Descours, A.; Aerts, L.; Michiels, J.; Heyndrickx, L.; Martin, L.; Vanham, G. CD4 mimetic miniproteins: Potent anti-HIV compounds with promising activity as microbicides. J Antimicrob. Chemother. 2008, 61, 818-826. [CrossRef]

69. Selhorst, P.; Grupping, K.; Tong, T.; Crooks, E.T.; Martin, L.; Vanham, G.; Binley, J.M.; Arien, K.K. M48U1 CD4 mimetic has a sustained inhibitory effect on cell-associated HIV-1 by attenuating virion infectivity through gp120 shedding. Retrovirology 2013, 10, 12. [CrossRef]

70. Dereuddre-Bosquet, N.; Morellato-Castillo, L.; Brouwers, J.; Augustijns, P.; Bouchemal, K.; Ponchel, G.; Ramos, O.H.; Herrera, C.; Stefanidou, M.; Shattock, R.; et al. MiniCD4 microbicide prevents HIV infection of human mucosal explants and vaginal transmission of SHIV(162P3) in cynomolgus macaques. PLoS Pathog. 2012, 8, e1003071. [CrossRef] 
71. Choi, Y.H.; Rho, W.S.; Kim, N.D.; Park, S.J.; Shin, D.H.; Kim, J.W.; Im, S.H.; Won, H.S.; Lee, C.W.; Chae, C.B.; et al. Short peptides with induced beta-turn inhibit the interaction between HIV-1 gp120 and CD4. J. Med. Chem. 2001, 44, 1356-1363. [CrossRef] [PubMed]

72. Ferrer, M.; Harrison, S.C. Peptide ligands to human immunodeficiency virus type 1 gp120 identified from phage display libraries. J. Virol. 1999, 73, 5795-5802.

73. Biorn, A.C.; Cocklin, S.; Madani, N.; Si, Z.; Ivanovic, T.; Samanen, J.; Van Ryk, D.I.; Pantophlet, R.; Burton, D.R.; Freire, E.; et al. Mode of action for linear peptide inhibitors of HIV-1 gp120 interactions. Biochemistry 2004, 43, 1928-1938. [CrossRef]

74. Celigoy, J.; Ramirez, B.; Tao, L.; Rong, L.; Yan, L.; Feng, Y.R.; Quinnan, G.V.; Broder, C.C.; Caffrey, M. Probing the HIV gp120 envelope glycoprotein conformation by NMR. J. Biol. Chem. 2011, 286, 23975-23981. [CrossRef] [PubMed]

75. Gopi, H.; Umashankara, M.; Pirrone, V.; LaLonde, J.; Madani, N.; Tuzer, F.; Baxter, S.; Zentner, I.; Cocklin, S.; Jawanda, N.; et al. Structural determinants for affinity enhancement of a dual antagonist peptide entry inhibitor of human immunodeficiency virus type-1. J. Med. Chem. 2008, 51, 2638-2647. [CrossRef] [PubMed]

76. Thali, M.; Moore, J.P.; Furman, C.; Charles, M.; Ho, D.D.; Robinson, J.; Sodroski, J. Characterization of conserved human immunodeficiency virus type 1 gp120 neutralization epitopes exposed upon gp120-CD4 binding. J. Virol. 1993, 67, 3978-3988. [PubMed]

77. Chen, W.; Zhu, Z.; Feng, Y.; Dimitrov, D.S. Human domain antibodies to conserved sterically restricted regions on gp120 as exceptionally potent cross-reactive HIV-1 neutralizers. Proc. Natl. Acad. Sci. USA 2008, 105, 17121-17126. [CrossRef] [PubMed]

78. Chen, W.; Xiao, X.; Wang, Y.; Zhu, Z.; Dimitrov, D.S. Bifunctional fusion proteins of the human engineered antibody domain m36 with human soluble CD4 are potent inhibitors of diverse HIV-1 isolates. Antivir. Res. 2010, 88, 107-115. [CrossRef]

79. Kwong, P.D.; Wyatt, R.; Robinson, J.; Sweet, R.W.; Sodroski, J.; Hendrickson, W.A. Structure of an HIV gp120 envelope glycoprotein in complex with the CD4 receptor and a neutralizing human antibody. Nature 1998, 393, 648-659. [CrossRef]

80. Wu, L.; Gerard, N.P.; Wyatt, R.; Choe, H.; Parolin, C.; Ruffing, N.; Borsetti, A.; Cardoso, A.A.; Desjardin, E.; Newman, W.; et al. CD4-induced interaction of primary HIV-1 gp120 glycoproteins with the chemokine receptor CCR-5. Nature 1996, 384, 179-183. [CrossRef]

81. Huang, C.C.; Venturi, M.; Majeed, S.; Moore, M.J.; Phogat, S.; Zhang, M.Y.; Dimitrov, D.S.; Hendrickson, W.A.; Robinson, J.; Sodroski, J.; et al. Structural basis of tyrosine sulfation and VH-gene usage in antibodies that recognize the HIV type 1 coreceptor-binding site on gp120. Proc. Natl. Acad. Sci. USA 2004, 101, 2706-2711. [CrossRef] [PubMed]

82. Xiang, S.H.; Wang, L.; Abreu, M.; Huang, C.C.; Kwong, P.D.; Rosenberg, E.; Robinson, J.E.; Sodroski, J. Epitope mapping and characterization of a novel CD4-induced human monoclonal antibody capable of neutralizing primary HIV-1 strains. Virology 2003, 315, 124-134. [CrossRef]

83. Xiang, S.H.; Farzan, M.; Si, Z.; Madani, N.; Wang, L.; Rosenberg, E.; Robinson, J.; Sodroski, J. Functional mimicry of a human immunodeficiency virus type 1 coreceptor by a neutralizing monoclonal antibody. J. Virol. 2005, 79, 6068-6077. [CrossRef] [PubMed]

84. Choe, H.; Li, W.; Wright, P.L.; Vasilieva, N.; Venturi, M.; Huang, C.C.; Grundner, C.; Dorfman, T.; Zwick, M.B.; Wang, L.; et al. Tyrosine sulfation of human antibodies contributes to recognition of the CCR5 binding region of HIV-1 gp120. Cell 2003, 114, 161-170. [CrossRef]

85. Cimbro, R.; Peterson, F.C.; Liu, Q.; Guzzo, C.; Zhang, P.; Miao, H.; Van Ryk, D.; Ambroggio, X.; Hurt, D.E.; De Gioia, L.; et al. Tyrosine-sulfated V2 peptides inhibit HIV-1 infection via coreceptor mimicry. E BioMedicine 2016, 10, 45-54. [CrossRef] [PubMed]

86. Farzan, M.; Vasilieva, N.; Schnitzler, C.E.; Chung, S.; Robinson, J.; Gerard, N.P.; Gerard, C.; Choe, H.; Sodroski, J. A tyrosine-sulfated peptide based on the N terminus of CCR5 interacts with a CD4-enhanced epitope of the HIV-1 gp120 envelope glycoprotein and inhibits HIV-1 entry. J. Biol. Chem. 2000, 275, 33516-21. [CrossRef] [PubMed]

87. Dorfman, T.; Moore, M.J.; Guth, A.C.; Choe, H.; Farzan, M. A tyrosine-sulfated peptide derived from the heavy-chain CDR3 region of an HIV-1-neutralizing antibody binds gp120 and inhibits HIV-1 infection. J. Biol. Chem. 2006, 281, 28529-35. [CrossRef] [PubMed] 
88. Trkola, A.; Purtscher, M.; Muster, T.; Ballaun, C.; Buchacher, A.; Sullivan, N.; Srinivasan, K.; Sodroski, J.; Moore, J.P.; Katinger, H. Human monoclonal antibody 2G12 defines a distinctive neutralization epitope on the gp120 glycoprotein of human immunodeficiency virus type 1. J. Virol. 1996, 70, 1100-1108.

89. Walker, L.M.; Phogat, S.K.; Chan-Hui, P.Y.; Wagner, D.; Phung, P.; Goss, J.L.; Wrin, T.; Simek, M.D.; Fling, S.; Mitcham, J.L.; et al. Broad and potent neutralizing antibodies from an African donor reveal a new HIV-1 vaccine target. Science 2009, 326, 285-289. [CrossRef]

90. Doores, K.J.; Burton, D.R. Variable loop glycan dependency of the broad and potent HIV-1-neutralizing antibodies PG9 and PG16. J. Virol. 2010, 84, 10510-10521. [CrossRef]

91. Euler, Z.; Bunnik, E.M.; Burger, J.A.; Boeser-Nunnink, B.D.; Grijsen, M.L.; Prins, J.M.; Schuitemaker, H. Activity of broadly neutralizing antibodies, including PG9, PG16, and VRC01, against recently transmitted subtype B HIV-1 variants from early and late in the epidemic. J. Virol. 2011, 85, 7236-7245. [CrossRef] [PubMed]

92. Bouvin-Pley, M.; Morgand, M.; Moreau, A.; Jestin, P.; Simonnet, C.; Tran, L.; Goujard, C.; Meyer, L.; Barin, F.; Braibant, M. Evidence for a continuous drift of the HIV-1 species towards higher resistance to neutralizing antibodies over the course of the epidemic. PLoS Pathog. 2013, 9, e1003477. [CrossRef] [PubMed]

93. Pace, C.S.; Song, R.; Ochsenbauer, C.; Andrews, C.D.; Franco, D.; Yu, J.; Oren, D.A.; Seaman, M.S.; Ho, D.D. Bispecific antibodies directed to CD4 domain 2 and HIV envelope exhibit exceptional breadth and picomolar potency against HIV-1. Proc. Natl. Acad. Sci. USA 2013, 110, 13540-13545. [CrossRef] [PubMed]

94. Mujib, S.; Liu, J.; Rahman, A.; Schwartz, J.A.; Bonner, P.; Yue, F.Y.; Ostrowski, M.A. Comprehensive cross-clade characterization of antibody-mediated recognition, complement-mediated lysis, and cell-mediated cytotoxicity of HIV-1 envelope-specific antibodies toward eradication of the HIV-1 reservoir. J. Virol. 2017, 91. [CrossRef] [PubMed]

95. Bonsignori, M.; Hwang, K.K.; Chen, X.; Tsao, C.Y.; Morris, L.; Gray, E.; Marshall, D.J.; Crump, J.A.; Kapiga, S.H.; Sam, N.E. Analysis of a clonal lineage of HIV-1 envelope V2/V3 conformational epitope-specific broadly neutralizing antibodies and their inferred unmutated common ancestors. J. Virol. 2011, 85, 9998-10009. [CrossRef] [PubMed]

96. Walker, L.M.; Huber, M.; Doores, K.J.; Falkowska, E.; Pejchal, R.; Julien, J.P.; Wang, S.K.; Ramos, A.; Chan-Hui, P.Y.; Moyle, M. Broad neutralization coverage of HIV by multiple highly potent antibodies. Nature 2011, 477, 466-470. [CrossRef] [PubMed]

97. Deshpande, S.; Patil, S.; Kumar, R.; Hermanus, T.; Murugavel, K.G.; Srikrishnan, A.K.; Solomon, S.; Morris, L.; Bhattacharya, J. HIV-1 clade C escapes broadly neutralizing autologous antibodies with N332 glycan specificity by distinct mechanisms. Retrovirology 2016, 13, 60. [CrossRef] [PubMed]

98. Mouquet, H.; Scharf, L.; Euler, Z.; Liu, Y.; Eden, C.; Scheid, J.F.; Halper-Stromberg, A.; Gnanapragasam, P.N.; Spencer, D.I.; Seaman, M.S. Complex-type N-glycan recognition by potent broadly neutralizing HIV antibodies. Proc. Natl. Acad. Sci. USA 2012, 109, E3268-E3277. [CrossRef]

99. Garces, F.; Sok, D.; Kong, L.; McBride, R.; Kim, H.J.; Saye-Francisco, K.F.; Julien, J.P.; Hua, Y.; Cupo, A.; Moore, J.P.; et al. Structural evolution of glycan recognition by a family of potent HIV antibodies. Cell 2014, 159, 69-79. [CrossRef]

100. Caskey, M.; Schoofs, T.; Gruell, H.; Settler, A.; Karagounis, T.; Kreider, E.F.; Murrell, B.; Pfeifer, N.; Nogueira, L.; Oliveira, T.Y.; et al. Antibody 10-1074 suppresses viremia in HIV-1-infected individuals. Nat. Med. 2017, 23, 185-191. [CrossRef]

101. Bar-On, Y.; Gruell, H.; Schoofs, T.; Pai, J.A.; Nogueira, L.; Butler, A.L.; Millard, K.; Lehmann, C.; Suarez, I.; Oliveira, T.Y.; et al. Safety and antiviral activity of combination HIV-1 broadly neutralizing antibodies in viremic individuals. Nat. Med. 2018, 24, 1701-1707. [CrossRef] [PubMed]

102. Mendoza, P.; Gruell, H.; Nogueira, L.; Pai, J.A.; Butler, A.L.; Millard, K.; Lehmann, C.; Suarez, I.; Oliveira, T.Y.; Lorenzi, J.C.C.; et al. Combination therapy with anti-HIV-1 antibodies maintains viral suppression. Nature 2018, 561, 479-484. [CrossRef] [PubMed]

103. Akkouh, O.; Ng, T.B.; Singh, S.S.; Yin, C.; Dan, X.; Chan, Y.S.; Pan, W.; Cheung, R.C. Lectins with anti-HIV activity: A review. Molecules 2015, 20, 648-668. [CrossRef] [PubMed]

104. Boyd, M.R.; Gustafson, K.R.; McMahon, J.B.; Shoemaker, R.H.; O’Keefe, B.R.; Mori, T.; Gulakowski, R.J.; $\mathrm{Wu}$, L.; Rivera, M.I.; Laurencot, C.M. Discovery of cyanovirin-N, a novel human immunodeficiency virus-inactivating protein that binds viral surface envelope glycoprotein gp120: Potential applications to microbicide development. Antimicrob. Agents Chemother. 1997, 41, 1521-1530. [CrossRef] [PubMed] 
105. Mori, T.; O’Keefe, B.R.; Sowder, R.C., 2nd; Bringans, S.; Gardella, R.; Berg, S.; Cochran, P.; Turpin, J.A.; Buckheit, R.W., Jr.; McMahon, J.B.; et al. Isolation and characterization of griffithsin, a novel HIV-inactivating protein, from the red alga Griffithsia sp. J. Biol. Chem. 2005, 280, 9345-9353. [CrossRef] [PubMed]

106. Alexandre, K.B.; Moore, P.L.; Nonyane, M.; Gray, E.S.; Ranchobe, N.; Chakauya, E.; McMahon, J.B.; O'Keefe, B.R.; Chikwamba, R.; Morris, L. Mechanisms of HIV-1 subtype C resistance to GRFT, CV-N and SVN. Virology 2013, 446, 66-76. [CrossRef] [PubMed]

107. Huang, X.; Jin, W.; Griffin, G.E.; Shattock, R.J.; Hu, Q. Removal of two high-mannose N-linked glycans on gp120 renders human immunodeficiency virus 1 largely resistant to the carbohydrate-binding agent griffithsin. J. Gen. Virol. 2011, 92, 2367-2373. [CrossRef] [PubMed]

108. Gondim, A.C.S.; Roberta da Silva, S.; Mathys, L.; Noppen, S.; Liekens, S.; Holanda Sampaio, A.; Nagano, C.S.; Renata Costa Rocha, C.; Nascimento, K.S.; Cavada, B.S.; et al. Potent antiviral activity of carbohydrate-specific algal and leguminous lectins from the Brazilian biodiversity. Medchemcomm 2019, 10, 390-398. [CrossRef]

109. Miller, M.D.; Geleziunas, R.; Bianchi, E.; Lennard, S.; Hrin, R.; Zhang, H.; Lu, M.; An, Z.; Ingallinella, P.; Finotto, M.; et al. A human monoclonal antibody neutralizes diverse HIV-1 isolates by binding a critical gp41 epitope. Proc. Natl. Acad. Sci. USA 2005, 102, 14759-14764. [CrossRef]

110. Vincent, N.; Malvoisin, E. Ability of antibodies specific to the HIV-1 envelope glycoprotein to block the fusion inhibitor T20 in a cell-cell fusion assay. Immunobiology 2012, 217, 943-950. [CrossRef]

111. Augusto, M.T.; Hollmann, A.; Troise, F.; Veiga, A.S.; Pessi, A.; Santos, N.C. Lipophilicity is a key factor to increase the antiviral activity of HIV neutralizing antibodies. Coll. Surf B Biointerfaces 2017, 152, 311-316. [CrossRef] [PubMed]

112. Augusto, M.T.; Hollmann, A.; Castanho, M.A.; Porotto, M.; Pessi, A.; Santos, N.C. Improvement of HIV fusion inhibitor C34 efficacy by membrane anchoring and enhanced exposure. J. Antimicrob. Chemother. 2014, 69, 1286-1297. [CrossRef] [PubMed]

113. Lacek, K.; Urbanowicz, R.A.; Troise, F.; De Lorenzo, C.; Severino, V.; Di Maro, A.; Tarr, A.W.; Ferrara, F.; Ploss, A.; Temperton, N.; et al. Dramatic potentiation of the antiviral activity of HIV antibodies by cholesterol conjugation. J. Biol. Chem. 2014, 289, 35015-35028. [CrossRef] [PubMed]

114. Corti, D.; Langedijk, J.P.; Hinz, A.; Seaman, M.S.; Vanzetta, F.; Fernandez-Rodriguez, B.M.; Silacci, C.; Pinna, D.; Jarrossay, D.; Balla-Jhagjhoorsingh, S.; et al. Analysis of memory B cell responses and isolation of novel monoclonal antibodies with neutralizing breadth from HIV-1-infected individuals. PLoS ONE 2010, 5, e8805. [CrossRef] [PubMed]

115. Sabin, C.; Corti, D.; Buzon, V.; Seaman, M.S.; Lutje Hulsik, D.; Hinz, A.; Vanzetta, F.; Agatic, G.; Silacci, C.; Mainetti, L.; et al. Crystal structure and size-dependent neutralization properties of HK20, a human monoclonal antibody binding to the highly conserved heptad repeat 1 of gp41. PLoS Pathog. 2010, 6, e1001195. [CrossRef] [PubMed]

116. Nelson, J.D.; Kinkead, H.; Brunel, F.M.; Leaman, D.; Jensen, R.; Louis, J.M.; Maruyama, T.; Bewley, C.A.; Bowdish, K.; Clore, G.M.; et al. Antibody elicited against the gp41 N-heptad repeat (NHR) coiled-coil can neutralize HIV-1 with modest potency but non-neutralizing antibodies also bind to NHR mimetics. Virology 2008, 377, 170-183. [CrossRef] [PubMed]

117. Deng, Y.; Zheng, Q.; Ketas, T.J.; Moore, J.P.; Lu, M. Protein design of a bacterially expressed HIV-1 gp41 fusion inhibitor. Biochemistry 2007, 46, 4360-4369. [CrossRef]

118. Pan, C.; Cai, L.; Lu, H.; Lu, L.; Jiang, S. A novel chimeric protein-based HIV-1 fusion inhibitor targeting gp41 glycoprotein with high potency and stability. J. Biol. Chem. 2011, 286, 28425-28434. [CrossRef]

119. Earl, P.L.; Broder, C.C.; Doms, R.W.; Moss, B. Epitope map of human immunodeficiency virus type 1 gp41 derived from 47 monoclonal antibodies produced by immunization with oligomeric envelope protein. J. Virol. 1997, 71, 2674-2684.

120. Dawood, R.; Benjelloun, F.; Pin, J.J.; Kone, A.; Chanut, B.; Jospin, F.; Lucht, F.; Verrier, B.; Moog, C.; Genin, C.; et al. Generation of HIV-1 potent and broad neutralizing antibodies by immunization with postfusion HR1/HR2 complex. Aids 2013, 27, 717-730. [CrossRef]

121. Trott, M.; Weibeta, S.; Antoni, S.; Koch, J.; von Briesen, H.; Hust, M.; Dietrich, U. Functional characterization of two scFv-Fc antibodies from an HIV controller selected on soluble HIV-1 Env complexes: A neutralizing V3- and a trimer-specific gp41 antibody. PLoS ONE 2014, 9, e97478. [CrossRef] [PubMed]

122. Louis, J.M.; Bewley, C.A.; Clore, G.M. Design and properties of N(CCG)-gp41, a chimeric gp41 molecule with nanomolar HIV fusion inhibitory activity. J. Biol. Chem. 2001, 276, 29485-29489. [CrossRef] [PubMed] 
123. Chen, X.; Lu, L.; Qi, Z.; Lu, H.; Wang, J.; Yu, X.; Chen, Y.; Jiang, S. Novel recombinant engineered gp41 $\mathrm{N}$-terminal heptad repeat trimers and their potential as anti-HIV-1 therapeutics or microbicides. J. Biol. Chem. 2010, 285, 25506-25515. [CrossRef] [PubMed]

124. Tong, P.; Lu, Z.; Chen, X.; Wang, Q.; Yu, F.; Zou, P.; Yu, X.; Li, Y.; Lu, L.; Chen, Y.H.; et al. An engineered HIV-1 gp41 trimeric coiled coil with increased stability and anti-HIV-1 activity: Implication for developing anti-HIV microbicides. J. Antimicrob. Chemother. 2013, 68, 2533-2544. [CrossRef] [PubMed]

125. Chen, C.H.; Greenberg, M.L.; Bolognesi, D.P.; Matthews, T.J. Monoclonal antibodies that bind to the core of fusion-active glycoprotein 41. AIDS Res. Hum. Retrov. 2000, 16, 2037-2041. [CrossRef] [PubMed]

126. Gorny, M.K.; Zolla-Pazner, S. Recognition by human monoclonal antibodies of free and complexed peptides representing the prefusogenic and fusogenic forms of human immunodeficiency virus type 1 gp41. J. Virol. 2000, 74, 6186-6192. [CrossRef] [PubMed]

127. Vincent, N.; Kone, A.; Chanut, B.; Lucht, F.; Genin, C.; Malvoisin, E. Antibodies purified from sera of HIV-1-infected patients by affinity on the heptad repeat region 1/heptad repeat region 2 complex of gp41 neutralize HIV-1 primary isolates. Aids 2008, 22, 2075-2085. [CrossRef]

128. Jiang, S.; Lin, K.; Lu, M. A conformation-specific monoclonal antibody reacting with fusion-active gp41 from the human immunodeficiency virus type 1 envelope glycoprotein. J. Virol. 1998, 72, 10213-10217.

129. Li, J.; Chen, X.; Huang, J.; Jiang, S.; Chen, Y.H. Identification of critical antibody-binding sites in the HIV-1 gp41 six-helix bundle core as potential targets for HIV-1 fusion inhibitors. Immunobiology 2009, 214, 51-60. [CrossRef]

130. Golding, H.; Zaitseva, M.; de Rosny, E.; King, L.R.; Manischewitz, J.; Sidorov, I.; Gorny, M.K.; Zolla-Pazner, S.; Dimitrov, D.S.; Weiss, C.D. Dissection of human immunodeficiency virus type 1 entry with neutralizing antibodies to gp41 fusion intermediates. J. Virol. 2002, 76, 6780-6790. [CrossRef]

131. Zhu, Y.; Lu, L.; Xu, L.; Yang, H.; Jiang, S.; Chen, Y.H. Identification of a gp41 core-binding molecule with homologous sequence of human TNNI3K-like protein as a novel human immunodeficiency virus type 1 entry inhibitor. J. Virol. 2010, 84, 9359-9368. [CrossRef] [PubMed]

132. Miyauchi, K.; Kim, Y.; Latinovic, O.; Morozov, V.; Melikyan, G.B. HIV enters cells via endocytosis and dynamin-dependent fusion with endosomes. Cell 2009, 137, 433-444. [CrossRef] [PubMed]

133. Chao, L.; Lu, L.; Yang, H.; Zhu, Y.; Li, Y.; Wang, Q.; Yu, X.; Jiang, S.; Chen, Y.H. Identification of a human protein-derived HIV-1 fusion inhibitor targeting the gp41 fusion core structure. PLOS ONE 2013, 8, e66156. [CrossRef] [PubMed]

134. Tan, Y.; Wang, J.; Su, S.; Wang, Q.; Jiang, S.; Lu, L.; Chen, Y.-H. Enhancement of endocytic uptake of HIV-1 virions into CD4-negative epithelial cells by HIV-1 gp41 via its interaction with POB1. Cell. Mol. Immunol. 2017, 14, 568-571. [CrossRef] [PubMed]

135. Sun, Z.; Zhu, Y.; Wang, Q.; Ye, L.; Dai, Y.; Su, S.; Yu, F.; Ying, T.; Yang, C.; Jiang, S.; et al. An immunogen containing four tandem 10E8 epitope repeats with exposed key residues induces antibodies that neutralize HIV-1 and activates an ADCC reporter gene. Emerg. Microbes. Infect. 2016, 5, e65. [CrossRef] [PubMed]

136. Muster, T.; Steindl, F.; Purtscher, M.; Trkola, A.; Klima, A.; Himmler, G.; Ruker, F.; Katinger, H. A conserved neutralizing epitope on gp41 of human immunodeficiency virus type 1. J. Virol. 1993, 67, 6642-6647. [PubMed]

137. Haynes, B.F.; Fleming, J.; St Clair, E.W.; Katinger, H.; Stiegler, G.; Kunert, R.; Robinson, J.; Scearce, R.M.; Plonk, K.; Staats, H.F.; et al. Cardiolipin polyspecific autoreactivity in two broadly neutralizing HIV-1 antibodies. Science 2005, 308, 1906-1908. [CrossRef]

138. Huang, J.; Ofek, G.; Laub, L.; Louder, M.K.; Doria-Rose, N.A.; Longo, N.S.; Imamichi, H.; Bailer, R.T.; Chakrabarti, B.; Sharma, S.K.; et al. Broad and potent neutralization of HIV-1 by a gp41-specific human antibody. Nature 2012, 491, 406-412. [CrossRef]

139. Kwon, Y.D.; Georgiev, I.S.; Ofek, G.; Zhang, B.; Asokan, M.; Bailer, R.T.; Bao, A.; Caruso, W.; Chen, X.; Choe, M.; et al. Optimization of the solubility of HIV-1-neutralizing antibody 10E8 through somatic variation and structure-based design. J. Virol. 2016, 90, 5899-5914. [CrossRef]

140. Huang, Y.; Yu, J.; Lanzi, A.; Yao, X.; Andrews, C.D.; Tsai, L.; Gajjar, M.R.; Sun, M.; Seaman, M.S.; Padte, N.N.; et al. Engineered bispecific antibodies with exquisite HIV-1-neutralizing activity. Cell 2016, 165, 1621-1631. [CrossRef]

141. Padte, N.N.; Yu, J.; Huang, Y.; Ho, D.D. Engineering multi-specific antibodies against HIV-1. Retrovirology 2018, 15, 60. [CrossRef] [PubMed] 
142. Munch, J.; Standker, L.; Adermann, K.; Schulz, A.; Schindler, M.; Chinnadurai, R.; Pohlmann, S.; Chaipan, C.; Biet, T.; Peters, T.; et al. Discovery and optimization of a natural HIV-1 entry inhibitor targeting the gp41 fusion peptide. Cell 2007, 129, 263-275. [CrossRef] [PubMed]

143. Jiang, X.; Jia, Q.; Lu, L.; Yu, F.; Zheng, J.; Shi, W.; Cai, L.; Jiang, S.; Liu, K. A novel bispecific peptide HIV-1 fusion inhibitor targeting the N-terminal heptad repeat and fusion peptide domains in gp41. Amino Acids 2016, 48, 2867-2873. [CrossRef] [PubMed]

144. Tillmann, H.L.; Heiken, H.; Knapik-Botor, A.; Heringlake, S.; Ockenga, J.; Wilber, J.C.; Goergen, B.; Detmer, J.; McMorrow, M.; Stoll, M.; et al. Infection with GB virus C and reduced mortality among HIV-infected patients. N. Engl. J. Med. 2001, 345, 715-724. [CrossRef] [PubMed]

145. De Miranda, B.K.B.; de Sa, K.S.G.; da Silva, A.N.R.; Feitosa, R.N.M.; Cayres-Vallinoto, I.M.V.; Ishak, R.; Vallinoto, A.C.R. GBV-C/HIV-1 coinfection is associated with low HIV-1 viral load and high CD4(+) T lymphocyte count. Arch. Virol. 2017, 162, 3431-3438. [CrossRef] [PubMed]

146. Shankar, E.M.; Balakrishnan, P.; Vignesh, R.; Velu, V.; Jayakumar, P.; Solomon, S. Current views on the pathophysiology of GB Virus C coinfection with HIV-1 infection. Curr. Infect. Dis. Rep. 2011, 13, 47-52. [CrossRef] [PubMed]

147. Sheng, W.H.; Hung, C.C.; Wu, R.J.; Wang, J.T.; Chen, P.J.; Chang, S.C.; Kao, J.H. Clinical impact of GB virus C viremia on patients with HIV type 1 infection in the era of highly active antiretroviral therapy. Clin. Infect. Dis. 2007, 44, 584-590. [CrossRef]

148. Sanchez-Martin, M.J.; Hristova, K.; Pujol, M.; Gomara, M.J.; Haro, I.; Alsina, M.A.; Busquets, M.A. Analysis of HIV-1 fusion peptide inhibition by synthetic peptides from E1 protein of GB virus C. J. Colloid. Interface Sci. 2011, 360, 124-131. [CrossRef]

149. Galatola, R.; Vasconcelos, A.; Perez, Y.; Cruz, A.; Pujol, M.; Alsina, M.A.; Gomara, M.J.; Haro, I. A cyclic GB virus $\mathrm{C}$ derived peptide with anti-HIV-1 activity targets the fusion peptide of HIV-1. Eur. J. Med. Chem. 2014, 86, 589-604. [CrossRef]

150. Galatola, R.; Cruz, A.; Gomara, M.J.; Prat, J.; Alsina, M.A.; Haro, I.; Pujol, M. Surface behavior of peptides from E1 GBV-C protein: Interaction with anionic model membranes and importance in HIV-1 FP inhibition. Biochim. Biophys. Acta 2015, 1848, 392-407. [CrossRef]

151. Koedel, Y.; Eissmann, K.; Wend, H.; Fleckenstein, B.; Reil, H. Peptides derived from a distinct region of GB virus C glycoprotein E2 mediate strain-specific HIV-1 entry inhibition. J. Virol. 2011, 85, 7037-7047. [CrossRef] [PubMed]

152. Herrera, E.; Tenckhoff, S.; Gomara, M.J.; Galatola, R.; Bleda, M.J.; Gil, C.; Ercilla, G.; Gatell, J.M.; Tillmann, H.L.; Haro, I. Effect of synthetic peptides belonging to E2 envelope protein of GB virus C on human immunodeficiency virus type 1 infection. J. Med. Chem. 2010, 53, 6054-6063. [CrossRef] [PubMed]

153. Jung, S.; Eichenmuller, M.; Donhauser, N.; Neipel, F.; Engel, A.M.; Hess, G.; Fleckenstein, B.; Reil, H. HIV entry inhibition by the envelope 2 glycoprotein of GB virus C. AIDS 2007, 21, 645-647. [CrossRef] [PubMed]

154. Gomara, M.J.; Sanchez-Merino, V.; Paus, A.; Merino-Mansilla, A.; Gatell, J.M.; Yuste, E.; Haro, I. Definition of an 18-mer synthetic peptide derived from the GB virus C E1 Protein as a new HIV-1 entry inhibitor. Biochim. Biophys. Acta 2016, 1860, 1139-1148. [CrossRef] [PubMed]

155. Xia, S.; Yan, L.; Xu, W.; Agrawal, A.S.; Algaissi, A.; Tseng, C.K.; Wang, Q.; Du, L.; Tan, W.; Wilson, I.A.; et al. A pan-coronavirus fusion inhibitor targeting the HR1 domain of human coronavirus spike. Sci. Adv. 2019, 5, eaav4580. [CrossRef] [PubMed]

156. Lu, L.; Liu, Q.; Zhu, Y.; Chan, K.H.; Qin, L.; Li, Y.; Wang, Q.; Chan, J.F.; Du, L.; Yu, F. Structure-based discovery of Middle East respiratory syndrome coronavirus fusion inhibitor. Nat. Commun. 2014, 5, 3067. [CrossRef] [PubMed]

157. Wang, X.; Zou, P.; Wu, F.; Lu, L.; Jiang, S. Development of small-molecule viral inhibitors targeting various stages of the life cycle of emerging and re-emerging viruses. Front. Med. 2017, 11, 449-461. [CrossRef] [PubMed]

158. Xia, S.; Xu, W.; Wang, Q.; Wang, C.; Hua, C.; Li, W.; Lu, L.; Jiang, S. Peptide-Based Membrane Fusion Inhibitors Targeting HCoV-229E Spike Protein HR1 and HR2 Domains. Int. J. Mol. Sci. 2018, $19,487$. [CrossRef]

159. Eckert, D.M.; Kim, P.S. Design of potent inhibitors of HIV-1 entry from the gp41 N-peptide region. Proc. Natl. Acad. Sci. USA 2001, 98, 11187-11192. [CrossRef] 
160. Cai, L.; Gochin, M.; Liu, K. Biochemistry and biophysics of HIV-1 gp41-Membrane interactions and implications for HIV-1 envelope protein mediated viral-cell fusion and fusion inhibitor design. Curr. Top. Med. Chem. 2011, 11, 2959-2984. [CrossRef]

161. Cai, L.; Jiang, S. Development of peptide and small-molecule HIV-1 fusion inhibitors that target gp41. ChemMedChem 2010, 5, 1813-1824. [CrossRef] [PubMed]

162. Pan, C.; Liu, S.; Jiang, S. HIV-1 gp41 fusion intermediate: A target for HIV therapeutics. J. Formos. Med. Assoc. 2010, 109, 94-105. [CrossRef]

163. Jiang, S.; Lin, K.; Strick, N.; Neurath, A.R. HIV-1 inhibition by a peptide. Nature 1993, 365, 113. [CrossRef] [PubMed]

164. Jiang, S.; Lin, K.; Strick, N.; Neurath, A.R. Inhibition of HIV-1 infection by a fusion domain binding peptide from the HIV-1 envelope glycoprotein GP41. Biochem. Biophys. Res. Commun. 1993, 195, 533-538. [CrossRef] [PubMed]

165. Wild, C.; Oas, T.; McDanal, C.; Bolognesi, D.; Matthews, T. A synthetic peptide inhibitor of human immunodeficiency virus replication: Correlation between solution structure and viral inhibition. Proc. Natl. Acad. Sci. USA 1992, 89, 10537-10541. [CrossRef] [PubMed]

166. Lu, M.; Blacklow, S.C.; Kim, P.S. A trimeric structural domain of the HIV-1 transmembrane glycoprotein. Nat. Struct. Biol. 1995, 2, 1075-1082. [CrossRef] [PubMed]

167. Liu, S.; Boyer-Chatenet, L.; Lu, H.; Jiang, S. Rapid and automated fluorescence-linked immunosorbent assay for high-throughput screening of HIV-1 fusion inhibitors targeting gp41. J. Biomol. Screen. 2003, 8, 685-693. [CrossRef]

168. Su, S.; Wang, Q.; Xu, W.; Yu, F.; Hua, C.; Zhu, Y.; Jiang, S.; Lu, L. A novel HIV-1 gp41 tripartite model for rational design of HIV-1 fusion inhibitors with improved antiviral activity. AIDS 2017, 31, 885-894. [CrossRef]

169. Sen, J.; Yan, T.; Wang, J.; Rong, L.; Tao, L.; Caffrey, M. Alanine scanning mutagenesis of HIV-1 gp41 heptad repeat 1: Insight into the gp120-gp41 interaction. Biochemistry 2010, 49, 5057-5065. [CrossRef]

170. Cai, L.; Gochin, M. A novel fluorescence intensity screening assay identifies new low-molecular-weight inhibitors of the gp41 coiled-coil domain of human immunodeficiency virus type 1. Antimicrob. Agents Chemother. 2007, 51, 2388-2395. [CrossRef]

171. Gochin, M.; Kiplin Guy, R.; Case, M.A. A metallopeptide assembly of the HIV-1 gp41 coiled coil is an ideal receptor in fluorescence detection of ligand binding. Angew. Chem. Int. Ed. Engl. 2003, 42, 5325-5328. [CrossRef] [PubMed]

172. Su, S.; Zhu, Y.; Ye, S.; Qi, Q.; Xia, S.; Ma, Z.; Yu, F.; Wang, Q.; Zhang, R.; Jiang, S.; et al. Creating an artificial tail anchor as a novel strategy to enhance the potency of peptide-based HIV fusion inhibitors. J. Virol. 2017, 91, e01445-16. [CrossRef] [PubMed]

173. Lalezari, J.P.; Henry, K.; O’Hearn, M.; Montaner, J.S.; Piliero, P.J.; Trottier, B.; Walmsley, S.; Cohen, C.; Kuritzkes, D.R.; Eron, J.J.; et al. Enfuvirtide, an HIV-1 fusion inhibitor, for drug-resistant HIV infection in North and South America. N. Engl. J. Med. 2003, 348, 2175-2185. [CrossRef] [PubMed]

174. Molina, J.M.; Lamarca, A.; Andrade-Villanueva, J.; Clotet, B.; Clumeck, N.; Liu, Y.P.; Zhong, L.; Margot, N.; Cheng, A.K.; Chuck, S.L. Efficacy and safety of once daily elvitegravir versus twice daily raltegravir in treatment-experienced patients with HIV-1 receiving a ritonavir-boosted protease inhibitor: Randomised, double-blind, phase 3, non-inferiority study. Lancet. Infect. Dis. 2012, 12, 27-35. [CrossRef]

175. Su, S.B.; Gong, W.H.; Gao, J.L.; Shen, W.P.; Grimm, M.C.; Deng, X.; Murphy, P.M.; Oppenheim, J.J.; Wang, J.M. T20/DP178, an ectodomain peptide of human immunodeficiency virus type $1 \mathrm{gp} 41$, is an activator of human phagocyte N-formyl peptide receptor. Blood 1999, 93, 3885-3892.

176. Ball, R.A.; Kinchelow, T. Injection site reactions with the HIV-1 fusion inhibitor enfuvirtide. J. Am. Acad. Dermatol. 2003, 49, 826-831. [CrossRef]

177. Maggi, P.; Ladisa, N.; Cinori, E.; Altobella, A.; Pastore, G.; Filotico, R. Cutaneous injection site reactions to long-term therapy with enfuvirtide. J. Antimicrob. Chemother. 2004, 53, 678-681. [CrossRef]

178. Liu, S.; Lu, H.; Niu, J.; Xu, Y.; Wu, S.; Jiang, S. Different from the HIV fusion inhibitor C34, the anti-HIV drug Fuzeon (T-20) inhibits HIV-1 entry by targeting multiple sites in gp41 and gp120. J. Biol. Chem. 2005, 280, 11259-11273. [CrossRef] 
179. Liu, S.; Jing, W.; Cheung, B.; Lu, H.; Sun, J.; Yan, X.; Niu, J.; Farmar, J.; Wu, S.; Jiang, S. HIV gp41 C-terminal heptad repeat contains multifunctional domains. Relation to mechanisms of action of anti-HIV peptides. J. Biol. Chem. 2007, 282, 9612-9620. [CrossRef]

180. Zhang, X.; Ding, X.; Zhu, Y.; Chong, H.; Cui, S.; He, J.; Wang, X.; He, Y. Structural and functional characterization of HIV-1 cell fusion inhibitor T20. AIDS 2019, 33, 1-11. [CrossRef]

181. Xu, W.; Pu, J.; Su, S.; Hua, C.; Su, X.; Wang, Q.; Jiang, S.; Lu, L. Revisiting the mechanism of enfuvirtide and designing an analog with improved fusion inhibitory activity by targeting triple sites in gp41. AIDS 2019, 33, 1545-1555. [CrossRef] [PubMed]

182. Otaka, A.; Nakamura, M.; Nameki, D.; Kodama, E.; Uchiyama, S.; Nakamura, S.; Nakano, H.; Tamamura, H.; Kobayashi, Y.; Matsuoka, M.; et al. Remodeling of gp41-C34 peptide leads to highly effective inhibitors of the fusion of HIV-1 with target cells. Angew. Chem. Int. Ed. Engl. 2002, 41, 2937-2940. [CrossRef]

183. Eggink, D.; Baldwin, C.E.; Deng, Y.; Langedijk, J.P.; Lu, M.; Sanders, R.W.; Berkhout, B. Selection of T1249-resistant human immunodeficiency virus type 1 variants. J. Virol. 2008, 82, 6678-6688. [CrossRef] [PubMed]

184. Dwyer, J.J.; Wilson, K.L.; Davison, D.K.; Freel, S.A.; Seedorff, J.E.; Wring, S.A.; Tvermoes, N.A.; Matthews, T.J.; Greenberg, M.L.; Delmedico, M.K. Design of helical, oligomeric HIV-1 fusion inhibitor peptides with potent activity against enfuvirtide-resistant virus. Proc. Natl. Acad. Sci. USA 2007, 104, 12772-12777. [CrossRef] [PubMed]

185. Naito, T.; Izumi, K.; Kodama, E.; Sakagami, Y.; Kajiwara, K.; Nishikawa, H.; Watanabe, K.; Sarafianos, S.G.; Oishi, S.; Fujii, N.; et al. SC29EK, a peptide fusion inhibitor with enhanced alpha-helicity, inhibits replication of human immunodeficiency virus type 1 mutants resistant to enfuvirtide. Antimicrob. Agents Chemother. 2009, 53, 1013-1018. [CrossRef] [PubMed]

186. Nishikawa, H.; Oishi, S.; Fujita, M.; Watanabe, K.; Tokiwa, R.; Ohno, H.; Kodama, E.; Izumi, K.; Kajiwara, K.; Naitoh, T.; et al. Identification of minimal sequence for HIV-1 fusion inhibitors. Bioorg. Med. Chem. 2008, 16, 9184-9187. [CrossRef]

187. Chong, H.; Yao, X.; Qiu, Z.; Sun, J.; Zhang, M.; Waltersperger, S.; Wang, M.; Liu, S.L.; Cui, S.; He, Y. Short-peptide fusion inhibitors with high potency against wild-type and enfuvirtide-resistant HIV-1. FASEB J. 2013, 27, 1203-1213. [CrossRef]

188. Pan, C.; Cai, L.; Lu, H.; Qi, Z.; Jiang, S. Combinations of the first and next generations of human immunodeficiency virus (HIV) fusion inhibitors exhibit a highly potent synergistic effect against enfuvirtide-sensitive and-resistant HIV type 1 strains. J. Virol. 2009, 83, 7862-7872. [CrossRef]

189. He, Y.; Xiao, Y.; Song, H.; Liang, Q.; Ju, D.; Chen, X.; Lu, H.; Jing, W.; Jiang, S.; Zhang, L. Design and evaluation of sifuvirtide, a novel HIV-1 fusion inhibitor. J. Biol. Chem. 2008, 283, 11126-11134. [CrossRef]

190. Yao, X.; Chong, H.; Zhang, C.; Waltersperger, S.; Wang, M.; Cui, S.; He, Y. Broad antiviral activity and crystal structure of HIV-1 fusion inhibitor sifuvirtide. J. Biol. Chem. 2012, 287, 6788-6796. [CrossRef]

191. Jette, L.; Leger, R.; Thibaudeau, K.; Benquet, C.; Robitaille, M.; Pellerin, I.; Paradis, V.; van Wyk, P.; Pham, K.; Bridon, D.P. Human growth hormone-releasing factor (hGRF)1-29-albumin bioconjugates activate the GRF receptor on the anterior pituitary in rats: Identification of CJC-1295 as a long-lasting GRF analog. Endocrinology 2005, 146, 3052-3058. [CrossRef] [PubMed]

192. Xie, D.; Yao, C.; Wang, L.; Min, W.; Xu, J.; Xiao, J.; Huang, M.; Chen, B.; Liu, B.; Li, X.; et al. An albumin-conjugated peptide exhibits potent anti-HIV activity and long in vivo half-life. Antimicrob. Agents Chemother. 2010, 54, 191-196. [CrossRef] [PubMed]

193. He, Y.; Cheng, J.; Lu, H.; Li, J.; Hu, J.; Qi, Z.; Liu, Z.; Jiang, S.; Dai, Q. Potent HIV fusion inhibitors against Enfuvirtide-resistant HIV-1 strains. Proc. Natl. Acad. Sci. USA 2008, 105, 16332-16337. [CrossRef] [PubMed]

194. Pan, C.; Lu, H.; Qi, Z.; Jiang, S. Synergistic efficacy of combination of enfuvirtide and sifuvirtide, the firstand next-generation HIV-fusion inhibitors. AIDS 2009, 23, 639-641. [CrossRef] [PubMed]

195. Xiong, S.; Borrego, P.; Ding, X.; Zhu, Y.; Martins, A.; Chong, H.; Taveira, N.; He, Y. A helical short-peptide fusion inhibitor with highly potent activity against human immunodeficiency virus type 1 (HIV-1), HIV-2, and simian immunodeficiency virus. J. Virol. 2017, 91, e01839-16. [CrossRef]

196. Chong, H.; Qiu, Z.; Su, Y.; Yang, L.; He, Y. Design of a highly potent HIV-1 fusion inhibitor targeting the gp41 pocket. AIDS 2015, 29, 13-21. [CrossRef] [PubMed] 
197. Zhu, X.; Zhu, Y.; Ye, S.; Wang, Q.; Xu, W.; Su, S.; Sun, Z.; Yu, F.; Liu, Q.; Wang, C.; et al. Improved pharmacological and structural properties of HIV fusion inhibitor AP3 over enfuvirtide: Highlighting advantages of artificial peptide strategy. Sci. Rep. 2015, 5, 13028. [CrossRef]

198. Zhu, Y.; Su, S.; Qin, L.; Wang, Q.; Shi, L.; Ma, Z.; Tang, J.; Jiang, S.; Lu, L.; Ye, S.; et al. Rational improvement of gp41-targeting HIV-1 fusion inhibitors: An innovatively designed Ile-Asp-Leu tail with alternative conformations. Sci. Rep. 2016, 6, 31983. [CrossRef]

199. Chong, H.; Wu, X.; Su, Y.; He, Y. Development of potent and long-acting HIV-1 fusion inhibitors. AIDS 2016, 30, 1187-1196. [CrossRef]

200. Ashkenazi, A.; Viard, M.; Unger, L.; Blumenthal, R.; Shai, Y. Sphingopeptides: Dihydrosphingosine-based fusion inhibitors against wild-type and enfuvirtide-resistant HIV-1. FASEB J. 2012, 26, 4628-4636. [CrossRef]

201. Urbanowicz, R.A.; Lacek, K.; Lahm, A.; Bienkowska-Szewczyk, K.; Ball, J.K.; Nicosia, A.; Cortese, R.; Pessi, A. Cholesterol conjugation potentiates the antiviral activity of an HIV immunoadhesin. J. Pept. Sci. 2015, 21, 743-749. [CrossRef] [PubMed]

202. Wexler-Cohen, Y.; Ashkenazi, A.; Viard, M.; Blumenthal, R.; Shai, Y. Virus-cell and cell-cell fusion mediated by the HIV-1 envelope glycoprotein is inhibited by short gp41 N-terminal membrane-anchored peptides lacking the critical pocket domain. FASEB J. 2010, 24, 4196-4202. [CrossRef] [PubMed]

203. Klug, Y.A.; Ashkenazi, A.; Viard, M.; Porat, Z.; Blumenthal, R.; Shai, Y. Early and late HIV-1 membrane fusion events are impaired by sphinganine lipidated peptides that target the fusion site. Biochem. J. 2014, 461, 213-222. [CrossRef] [PubMed]

204. Lim, S.B.; Banerjee, A.; Onyuksel, H. Improvement of drug safety by the use of lipid-based nanocarriers. J. Control. Release. 2012, 163, 34-45. [CrossRef] [PubMed]

205. Chong, H.; Xue, J.; Xiong, S.; Cong, Z.; Ding, X.; Zhu, Y.; Liu, Z.; Chen, T.; Feng, Y.; He, L.; et al. A lipopeptide HIV-1/2 fusion inhibitor with highly potent in vitro, ex vivo and in vivo antiviral activity. J. Virol. 2017, 91, e00288-17. [CrossRef] [PubMed]

206. Ding, X.; Zhang, X.; Chong, H.; Zhu, Y.; Wei, H.; Wu, X.; He, J.; Wang, X.; He, Y. Enfuvirtide (T20)-based lipopeptide is a potent HIV-1 cell fusion inhibitor: Implications for viral entry and inhibition. J. Virol. 2017, 91, e00831-17. [CrossRef] [PubMed]

207. Zhu, Y.; Zhang, X.; Ding, X.; Chong, H.; Cui, S.; He, J.; Wang, X.; He, Y. Exceptional potency and structural basis of a T1249-derived lipopeptide fusion inhibitor against HIV-1, HIV-2, and simian immunodeficiency virus. J. Biol. Chem. 2018, 293, 5323-5334. [CrossRef] [PubMed]

208. Su, S.; Ma, Z.; Hua, C.; Li, W.; Lu, L.; Jiang, S. Adding an Artificial Tail-Anchor to a Peptide-Based HIV-1 Fusion Inhibitor for Improvement of Its Potency and Resistance Profile. Molecules 2017, 22, 1996. [CrossRef]

209. Su, S.; Rasquinha, G.; Du, L.; Wang, Q.; Xu, W.; Li, W.; Lu, L.; Jiang, S. A Peptide-Based HIV-1 Fusion Inhibitor with Two Tail-Anchors and Palmitic Acid Exhibits Substantially Improved In Vitro and Ex Vivo Anti-HIV-1 Activity and Prolonged In Vivo Half-Life. Molecules 2019, 24, 1134. [CrossRef]

210. Chong, H.; Zhu, Y.; Yu, D.; He, Y. Structural and functional characterization of membrane fusion inhibitors with extremely potent activity against human immunodeficiency virus type 1 (HIV-1), HIV-2, and simian immunodeficiency virus. J. Virol. 2018, 92, e01088-18. [CrossRef]

211. Ingallinella, P.; Bianchi, E.; Ladwa, N.A.; Wang, Y.J.; Hrin, R.; Veneziano, M.; Bonelli, F.; Ketas, T.J.; Moore, J.P.; Miller, M.D.; et al. Addition of a cholesterol group to an HIV-1 peptide fusion inhibitor dramatically increases its antiviral potency. Proc. Natl. Acad. Sci. USA 2009, 106, 5801-5806. [CrossRef] [PubMed]

212. Zhang, L.; Bulaj, G. Converting peptides into drug leads by lipidation. Curr. Med. Chem. 2012, 19, 1602-1618. [CrossRef] [PubMed]

213. Chazal, N.; Gerlier, D. Virus entry, assembly, budding, and membrane rafts. Microbiol. Mol. Biol. Rev. 2003, 67, 226-237. [CrossRef]

214. Carter, G.C.; Bernstone, L.; Sangani, D.; Bee, J.W.; Harder, T.; James, W. HIV entry in macrophages is dependent on intact lipid rafts. Virology 2009, 386, 192-202. [CrossRef] [PubMed]

215. Liu, L.; Wen, M.; Zhu, Q.; Kimata, J.T.; Zhou, P. Glycosyl phosphatidylinositol-anchored C34 peptide derived from human immunodeficiency virus type $1 \mathrm{gp} 41$ is a potent entry inhibitor. J. Neuroimmune Pharmacol. 2016, 11, 601-610. [CrossRef] [PubMed]

216. Lu, M.; Kim, P.S. A trimeric structural subdomain of the HIV-1 transmembrane glycoprotein. J. Biomol. Struct. Dyn. 1997, 15, 465-471. [CrossRef] 
217. Bewley, C.A.; Louis, J.M.; Ghirlando, R.; Clore, G.M. Design of a novel peptide inhibitor of HIV fusion that disrupts the internal trimeric coiled-coil of gp41. J. Biol. Chem. 2002, 277, 14238-14245. [CrossRef]

218. Wexler-Cohen, Y.; Shai, Y. Membrane-anchored HIV-1 N-heptad repeat peptides are highly potent cell fusion inhibitors via an altered mode of action. PLoS Pathog. 2009, 5, e1000509. [CrossRef]

219. Scharf, L.; Scheid, J.F.; Lee, J.H.; West, A.P., Jr.; Chen, C.; Gao, H.; Gnanapragasam, P.N.; Mares, R.; Seaman, M.S.; Ward, A.B.; et al. Antibody 8ANC195 reveals a site of broad vulnerability on the HIV-1 envelope spike. Cell Rep. 2014, 7, 785-795. [CrossRef]

220. Huang, J.; Kang, B.H.; Pancera, M.; Lee, J.H.; Tong, T.; Feng, Y.; Imamichi, H.; Georgiev, I.S.; Chuang, G.Y.; Druz, A.; et al. Broad and potent HIV-1 neutralization by a human antibody that binds the gp41-gp120 interface. Nature 2014, 515, 138-142. [CrossRef]

221. Kong, R.; Xu, K.; Zhou, T.; Acharya, P.; Lemmin, T.; Liu, K.; Ozorowski, G.; Soto, C.; Taft, J.D.; Bailer, R.T.; et al. Fusion peptide of HIV-1 as a site of vulnerability to neutralizing antibody. Science 2016, 352, 828-833. [CrossRef] [PubMed]

222. Falkowska, E.; Le, K.M.; Ramos, A.; Doores, K.J.; Lee, J.H.; Blattner, C.; Ramirez, A.; Derking, R.; van Gils, M.J.; Liang, C.H.; et al. Broadly neutralizing HIV antibodies define a glycan-dependent epitope on the prefusion conformation of gp41 on cleaved envelope trimers. Immunity 2014, 40, 657-668. [CrossRef]

223. Blattner, C.; Lee, J.H.; Sliepen, K.; Derking, R.; Falkowska, E.; de la Pena, A.T.; Cupo, A.; Julien, J.P.; van Gils, M.; Lee, P.S.; et al. Structural delineation of a quaternary, cleavage-dependent epitope at the gp41-gp120 interface on intact HIV-1 Env trimers. Immunity 2014, 40, 669-680. [CrossRef] [PubMed]

224. Van Gils, M.J.; van den Kerkhof, T.L.; Ozorowski, G.; Cottrell, C.A.; Sok, D.; Pauthner, M.; Pallesen, J.; de Val, N.; Yasmeen, A.; de Taeye, S.W.; et al. An HIV-1 antibody from an elite neutralizer implicates the fusion peptide as a site of vulnerability. Nat. Microbiol. 2016, 2, 16199. [CrossRef] [PubMed]

225. Klein, F.; Gaebler, C.; Mouquet, H.; Sather, D.N.; Lehmann, C.; Scheid, J.F.; Kraft, Z.; Liu, Y.; Pietzsch, J.; Hurley, A.; et al. Broad neutralization by a combination of antibodies recognizing the CD4 binding site and a new conformational epitope on the HIV-1 envelope protein. J. Exp. Med. 2012, 209, 1469-1479. [CrossRef]

226. Lee, J.H.; Leaman, D.P.; Kim, A.S.; Torrents de la Pena, A.; Sliepen, K.; Yasmeen, A.; Derking, R.; Ramos, A.; de Taeye, S.W.; Ozorowski, G.; et al. Antibodies to a conformational epitope on gp41 neutralize HIV-1 by destabilizing the Env spike. Nat. Commun. 2015, 6, 8167. [CrossRef]

227. Wibmer, C.K.; Gorman, J.; Ozorowski, G.; Bhiman, J.N.; Sheward, D.J.; Elliott, D.H.; Rouelle, J.; Smira, A.; Joyce, M.G.; Ndabambi, N.; et al. Structure and recognition of a novel HIV-1 gp120-gp41 interface antibody that caused MPER exposure through viral escape. PLoS Pathog 2017, 13, e1006074. [CrossRef]

228. Zhang, M.Y.; Yuan, T.; Li, J.; Rosa Borges, A.; Watkins, J.D.; Guenaga, J.; Yang, Z.; Wang, Y.; Wilson, R.; Li, Y. Identification and characterization of a broadly cross-reactive HIV-1 human monoclonal antibody that binds to both gp120 and gp41. PLOS ONE. 2012, 7, e44241.

229. Lu, L.; Pan, C.; Li, Y.; Lu, H.; He, W.; Jiang, S. A bivalent recombinant protein inactivates HIV-1 by targeting the gp41 prehairpin fusion intermediate induced by CD4 D1D2 domains. Retrovirology 2012, 9, 104. [CrossRef]

230. Xu, W.; Wang, Q.; Yu, F.; Lu, L.; Jiang, S. Synergistic effect resulting from combinations of a bifunctional HIV-1 antagonist with antiretroviral drugs. J. Acquir. Immune Defic. Syndr. 2014, 67, 1-6. [CrossRef]

231. Pusch, O.; Kalyanaraman, R.; Tucker, L.D.; Wells, J.M.; Ramratnam, B.; Boden, D. An anti-HIV microbicide engineered in commensal bacteria: Secretion of HIV-1 fusion inhibitors by lactobacilli. AIDS 2006, 20, 1917-1922. [CrossRef] [PubMed]

232. Falkenhagen, A.; Ameli, M.; Asad, S.; Read, S.E.; Joshi, S. A novel gene therapy strategy using secreted multifunctional anti-HIV proteins to confer protection to gene-modified and unmodified target cells. Gene Ther. 2014, 21, 175-187. [CrossRef] [PubMed]

233. Falkenhagen, A.; Joshi, S. Further characterization of the bifunctional HIV entry inhibitor sCD4-FIT45. Mol. Ther. Nucleic Acids 2017, 7, 387-395. [CrossRef] [PubMed]

234. Kagiampakis, I.; Gharibi, A.; Mankowski, M.K.; Snyder, B.A.; Ptak, R.G.; Alatas, K.; LiWang, P.J. Potent strategy to inhibit HIV-1 by binding both gp120 and gp41. Antimicrob. Agents Chemother. 2011, 55, 264-275. [CrossRef] [PubMed]

235. Sun, M.; Li, Y.; Yuan, Z.; Lu, W.; Kang, G.; Fan, W.; Li, Q. VRC01 antibody protects against vaginal and rectal transmission of human immunodeficiency virus 1 in hu-BLT mice. Arch. Virol. 2016, 161, 2449-2455. [CrossRef] [PubMed] 
236. Pegu, A.; Yang, Z.Y.; Boyington, J.C.; Wu, L.; Ko, S.Y.; Schmidt, S.D.; McKee, K.; Kong, W.P.; Shi, W.; Chen, X.; et al. Neutralizing antibodies to HIV-1 envelope protect more effectively in vivo than those to the CD4 receptor. Sci. Transl. Med. 2014, 6, 243ra88. [CrossRef] [PubMed]

237. Sanhadji, K.; Grave, L.; Touraine, J.L.; Leissner, P.; Rouzioux, C.; Firouzi, R.; Kehrli, L.; Tardy, J.C.; Mehtali, M. Gene transfer of anti-gp41 antibody and CD4 immunoadhesin strongly reduces the HIV-1 load in humanized severe combined immunodeficient mice. AIDS 2000, 14, 2813-2822. [CrossRef] [PubMed]

238. Lazzarin, A.; Clotet, B.; Cooper, D.; Reynes, J.; Arasteh, K.; Nelson, M.; Katlama, C.; Stellbrink, H.J.; Delfraissy, J.F.; Lange, J.; et al. Efficacy of enfuvirtide in patients infected with drug-resistant HIV-1 in Europe and Australia. N. Engl. J. Med. 2003, 348, 2186-2195. [CrossRef] [PubMed]

239. Walmsley, S.; Henry, K.; Katlama, C.; Nelson, M.; Castagna, A.; Reynes, J.; Clotet, B.; Hui, J.; Salgo, M.; DeMasi, R.; et al. Enfuvirtide (T-20) cross-reactive glycoprotein 41 antibody does not impair the efficacy or safety of enfuvirtide. J Infect. Dis. 2003, 188, 1827-1833. [CrossRef]

240. Kilby, J.M.; Lalezari, J.P.; Eron, J.J.; Carlson, M.; Cohen, C.; Arduino, R.C.; Goodgame, J.C.; Gallant, J.E.; Volberding, P.; Murphy, R.L.; et al. The safety, plasma pharmacokinetics, and antiviral activity of subcutaneous enfuvirtide (T-20), a peptide inhibitor of gp41-mediated virus fusion, in HIV-infected adults. AIDS Res. Hum. Retroviruses 2002, 18, 685-693. [CrossRef]

241. Stoddart, C.A.; Nault, G.; Galkina, S.A.; Thibaudeau, K.; Bakis, P.; Bousquet-Gagnon, N.; Robitaille, M.; Bellomo, M.; Paradis, V.; Liscourt, P.; et al. Albumin-conjugated C34 peptide HIV-1 fusion inhibitor: Equipotent to C34 and T-20 in vitro with sustained activity in SCID-hu Thy/Liv mice. J. Biol. Chem. 2008, 283, 34045-34052. [CrossRef] [PubMed]

242. Moldt, B.; Shibata-Koyama, M.; Rakasz, E.G.; Schultz, N.; Kanda, Y.; Dunlop, D.C.; Finstad, S.L.; Jin, C.; Landucci, G.; Alpert, M.D.; et al. A nonfucosylated variant of the anti-HIV-1 monoclonal antibody b12 has enhanced FcgammaRIIIa-mediated antiviral activity in vitro but does not improve protection against mucosal SHIV challenge in macaques. J. Virol. 2012, 86, 6189-6196. [CrossRef] [PubMed]

243. Cavacini, L.A.; Power, J.; Emes, C.L.; Mace, K.; Treacy, G.; Posner, M.R. Plasma pharmacokinetics and biological activity of a human immunodeficiency virus type 1 neutralizing human monoclonal antibody, F105, in cynomolgus monkeys. J. Immunother. Emphas. Tumor Immunol. 1994, 15, 251-256. [CrossRef]

244. Luo, X.M.; Lei, M.Y.; Feidi, R.A.; West, A.P., Jr.; Balazs, A.B.; Bjorkman, P.J.; Yang, L.; Baltimore, D. Dimeric 2G12 as a potent protection against HIV-1. PLoS Pathog 2010, 6, e1001225. [CrossRef] [PubMed]

245. Joseph, A.; Zheng, J.H.; Chen, K.; Dutta, M.; Chen, C.; Stiegler, G.; Kunert, R.; Follenzi, A.; Goldstein, H. Inhibition of in vivo HIV infection in humanized mice by gene therapy of human hematopoietic stem cells with a lentiviral vector encoding a broadly neutralizing anti-HIV antibody. J. Virol. 2010, 84, 6645-6653. [CrossRef] [PubMed]

246. Malherbe, D.C.; Sanders, R.W.; van Gils, M.J.; Park, B.; Gomes, M.M.; Schuitemaker, H.; Barnett, S.; Haigwood, N.L. HIV-1 envelope glycoprotein resistance to monoclonal antibody 2G12 is subject-specific and context-dependent in macaques and humans. PLoS ONE 2013, 8, e75277. [CrossRef]

247. Horwitz, J.A.; Halper-Stromberg, A.; Mouquet, H.; Gitlin, A.D.; Tretiakova, A.; Eisenreich, T.R.; Malbec, M.; Gravemann, S.; Billerbeck, E.; Dorner, M.; et al. HIV-1 suppression and durable control by combining single broadly neutralizing antibodies and antiretroviral drugs in humanized mice. Proc. Natl. Acad. Sci. USA 2013, 110, 16538-16543. [CrossRef]

248. Gautam, R.; Nishimura, Y.; Pegu, A.; Nason, M.C.; Klein, F.; Gazumyan, A.; Golijanin, J.; Buckler-White, A.; Sadjadpour, R.; Wang, K.; et al. A single injection of anti-HIV-1 antibodies protects against repeated SHIV challenges. Nature 2016, 533, 105-109. [CrossRef]

249. Badamchi-Zadeh, A.; Tartaglia, L.J.; Abbink, P.; Bricault, C.A.; Liu, P.T.; Boyd, M.; Kirilova, M.; Mercado, N.B.; Nanayakkara, O.S.; Vrbanac, V.D.; et al. Therapeutic efficacy of vectored PGT121 gene delivery in HIV-1-infected humanized mice. J. Virol. 2018, 92, e01925-17. [CrossRef]

250. Moldt, B.; Rakasz, E.G.; Schultz, N.; Chan-Hui, P.Y.; Swiderek, K.; Weisgrau, K.L.; Piaskowski, S.M.; Bergman, Z.; Watkins, D.I.; Poignard, P.; et al. Highly potent HIV-specific antibody neutralization in vitro translates into effective protection against mucosal SHIV challenge in vivo. Proc. Natl. Acad. Sci. USA 2012, 109, 18921-18925. [CrossRef]

251. Pfeifer, N.; Walter, H.; Lengauer, T. Association between HIV-1 coreceptor usage and resistance to broadly neutralizing antibodies. J. Acquir. Immune Defic. Syndr. 2014, 67, 107-112. [CrossRef] [PubMed] 
252. Rosenberg, Y.; Sack, M.; Montefiori, D.; Labranche, C.; Lewis, M.; Urban, L.; Mao, L.; Fischer, R.; Jiang, X. Pharmacokinetics and immunogenicity of broadly neutralizing HIV monoclonal antibodies in macaques. PLoS ONE 2015, 10, e0120451. [CrossRef] [PubMed]

253. Hu, B.; Du, T.; Li, C.; Luo, S.; Liu, Y.; Huang, X.; Hu, Q. Sensitivity of transmitted and founder human immunodeficiency virus type 1 envelopes to carbohydrate-binding agents griffithsin, cyanovirin-N and Galanthus nivalis agglutinin. J. Gen. Virol. 2015, 96, 3660-3666. [CrossRef] [PubMed]

254. Veazey, R.S.; Klasse, P.J.; Schader, S.M.; Hu, Q.; Ketas, T.J.; Lu, M.; Marx, P.A.; Dufour, J.; Colonno, R.J.; Shattock, R.J.; et al. Protection of macaques from vaginal SHIV challenge by vaginally delivered inhibitors of virus-cell fusion. Nature 2005, 438, 99-102. [CrossRef] [PubMed]

255. Denton, P.W.; Othieno, F.; Martinez-Torres, F.; Zou, W.; Krisko, J.F.; Fleming, E.; Zein, S.; Powell, D.A.; Wahl, A.; Kwak, Y.T.; et al. One percent tenofovir applied topically to humanized BLT mice and used according to the CAPRISA 004 experimental design demonstrates partial protection from vaginal HIV infection, validating the BLT model for evaluation of new microbicide candidates. J. Virol. 2011, 85, 7582-7593. [CrossRef]

256. Ni, L.; Gao, G.F.; Tien, P. Rational design of highly potent HIV-1 fusion inhibitory proteins: Implication for developing antiviral therapeutics. Biochem. Biophys. Res. Commun. 2005, 332, 831-836. [CrossRef] [PubMed]

257. Ren, Y.; Li, L.; Wan, Y.; Wang, W.; Wang, J.; Chen, J.; Wei, Q.; Qin, C.; Xu, J.; Zhang, X. Mucosal topical microbicide candidates exert influence on the subsequent SIV infection and survival by regulating SIV-specific T-cell immune responses. J. Acquir. Immune Defic. Syndr. 2016, 71, 121-129. [CrossRef]

258. Li, L.; Ben, Y.; Yuan, S.; Jiang, S.; Xu, J.; Zhang, X. Efficacy, stability, and biosafety of sifuvirtide gel as a microbicide candidate against HIV-1. PLoS ONE 2012, 7, e37381. [CrossRef]

259. Barouch, D.H.; Klasse, P.J.; Dufour, J.; Veazey, R.S.; Moore, J.P. Macaque studies of vaccine and microbicide combinations for preventing HIV-1 sexual transmission. Proc. Natl. Acad. Sci. USA 2012, 109, 8694-8698. [CrossRef]

260. Veazey, R.S.; Ketas, T.A.; Klasse, P.J.; Davison, D.K.; Singletary, M.; Green, L.C.; Greenberg, M.L.; Moore, J.P. Tropism-independent protection of macaques against vaginal transmission of three SHIVs by the HIV-1 fusion inhibitor T-1249. Proc. Natl. Acad. Sci. USA 2008, 105, 10531-10536. [CrossRef]

261. Root, M.J.; Kay, M.S.; Kim, P.S. Protein design of an HIV-1 entry inhibitor. Science 2001, 291, 884-888. [CrossRef] [PubMed]

262. Qiu, Z.; Chong, H.; Yao, X.; Su, Y.; Cui, S.; He, Y. Identification and characterization of a subpocket on the N-trimer of HIV-1 gp41: Implication for viral entry and drug target. AIDS 2015, 29, 1015-1024. [CrossRef] [PubMed]

263. Izumi, K.; Nakamura, S.; Nakano, H.; Shimura, K.; Sakagami, Y.; Oishi, S.; Uchiyama, S.; Ohkubo, T.; Kobayashi, Y.; Fujii, N.; et al. Characterization of HIV-1 resistance to a fusion inhibitor, N36, derived from the gp41 amino-terminal heptad repeat. Antivir. Res. 2010, 87, 179-186. [CrossRef] [PubMed]

264. West, A.P., Jr.; Scharf, L.; Horwitz, J.; Klein, F.; Nussenzweig, M.C.; Bjorkman, P.J. Computational analysis of anti-HIV-1 antibody neutralization panel data to identify potential functional epitope residues. Proc. Natl. Acad. Sci. USA 2013, 110, 10598-10603. [CrossRef] [PubMed]

(C) 2019 by the authors. Licensee MDPI, Basel, Switzerland. This article is an open access article distributed under the terms and conditions of the Creative Commons Attribution (CC BY) license (http://creativecommons.org/licenses/by/4.0/). 